J. Product. \& Dev., 15(1): 69- 103(2010)

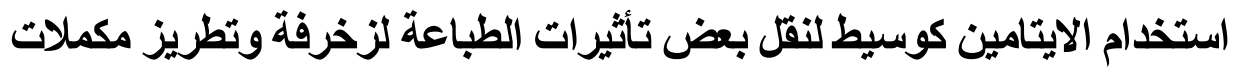

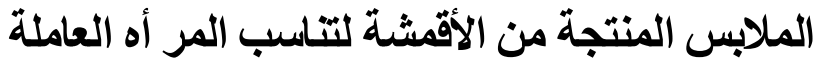

دار رشا عباس محمد متولي الجوهري

قسم الاقتصاد المنزلي -بكلية التربية النو عية -جامعة المنصورة- المنصورة- ج.م.ع.

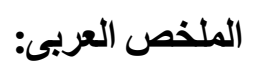

يههف البحث إلى الاستفادة من قماش الايتامين كوسيط فى عملية الطباعة بالاستتسل على

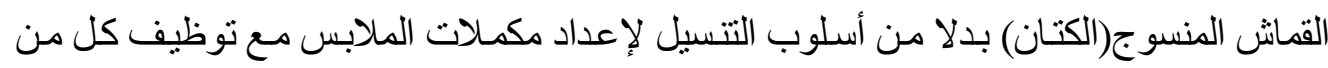

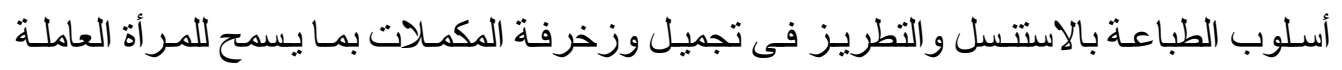
استخدامها بما يحقق المظهر الأثيق الى جانب الاقتصاد فى التكلفة.

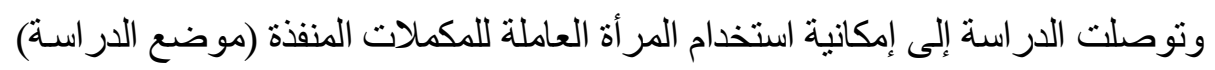

و أهمية المكملات المصنعة من الأقمشة بالنسبة للمر أة العاملة حيث تعتبر مكملات الزى ذات التهات أهمية

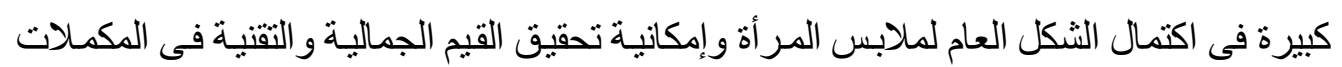
باستخدام اسلوبى الطباعة و التطريز للأقشة.

\section{مقدمســـة Introduction}

تعتبر ظاهرة التزين و التخلى ظاهرة إنسانية راقية تطبع عليها الإنسان منذ القدم، وبين

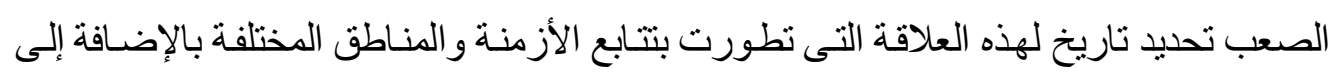

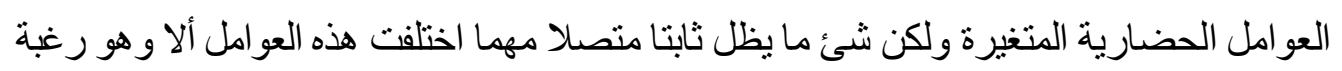

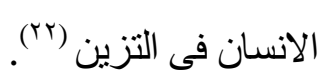
والإكسسوار هو مكملات الزينـة التى تساعد على إظهار أناقـة المر أة وزيهـا ، ويعتبر

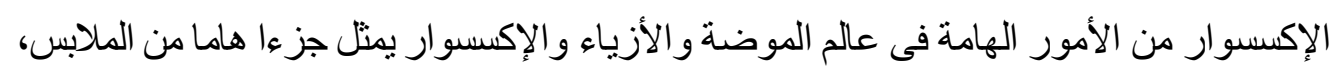

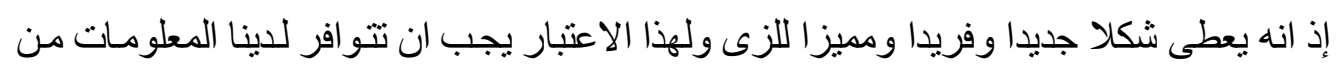

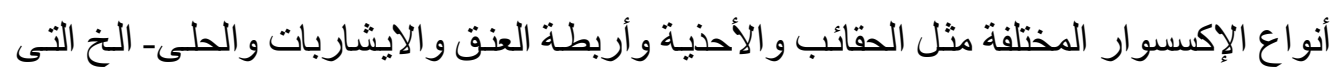

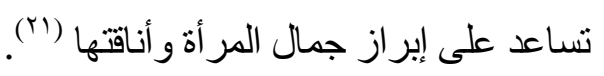
فكملات الملابس هى التفاصيل السحرية للموضة و التى يمكن عن طريقها تغيير الشعور الكلى بالمظهر الخارجى للفرد، و هى تللك الاضافات التى تزيد او تتقص من المظهر الخارجى للفرد. 
و إذا كان اختبار الفرد مناسب لمكملاته ، فإن ذلك يؤدى إلى مزيد من الرقى والشعور بالثقة

بالنفس فى المظهر الملبسى مما يجعله يبدو أفضل مما هو عليه بالفعل (9). و الإكسسوار هام جدا بالنسبة للزى وللفرد على حد سواء فاستخدام الاكسسوار الذى يلائم الزى من حيث اللون والمناسبة من العو امل التى تزيد من ثقة المر أة بنفسها عملياو اجتماعيا، كما ان خروج المر أة للعمل دفعها الى الاهتمام باستخدام الاكسسوار ات المناسبة للفترات المختلفة من النهار، فللصباح اكسسواره كما أن للمساء الاكسسوار المناسب له (rآ). ومكملات الملابس المصنو عة من القماش ذات خامـات وتقنيات متعددة، فهناك العديد من الاقششة التى يصلح استخدامها لعمل المكملات فى الاوقات و المناسبات المختلفة، وكنلك هنالك العديد من اساليب التقنية التى تستخدم مع هذه الخامات لتبرز جمالها للوصول الى منتج ذو ذوق فنى راقى من مكملات الملابس (r) ومن أهم هذه التقتيات الطباعة والتطريز: فالطباعة هي الطريقة المستخدمة للحصول على أشكال زخرفية نماذج أو رسومات ملونة بطرق مختلفة على شتى أنواع النسيج المعروفة ليكتسب مظهر ا جماليا ويحقق وظائف استعمالية تختلف باختلاف ظروف استخدامه. و التطريز يعد أحد المصادر الرئيسية لإعطاء تأثير ات وملابس مختلفة لسطح النسيج باستخدام الغرز الزخرفية والخيوط المختلفة، ولم يكن فن التطريز على مر العصور منفصلا عن الموضة بل كان هناك ارتباط وتكامل بين التطريز وتصميم الزى حيث كانت الزخارف تضاف إلى الملابس ومكملاتها على مر العصور (ء').

\section{Research Problem: مشكلة البحث}

كان من المعتاد استخدام أسلوب التسيل لأقمشة الإيتامين وذللك عند التطريز على الأقمشة التى لا يمكن عد خيوطها. حيث يتت استخدام قماث الإيتامين كخلفية لعمل الغرز المتقاطعة فوق

القماش وذللك كما هو موضح بالثكل رقم (1) حيث فيها يتم تثبيت نسيج الإيتامين فوق القطعة المراد تطريز هـا على أن يكون الإيتامين أكبر من القطعة المر اد تطريزها حتى يسهل تتسيل خيوط الإيتامين بعد الانتهاء من التطريز. 
• عند الاتنهاء من التطريز نبدأ بقص قماش الإيتامين من حول الوحدة المطرزة. • مع ملاحظة ترك نهايات طويلة كفاية من خيوط الإيتامين لسحبها. • • يتم سحب كل الخيوط الفردية (بقايا الخيوط) للخارج من خلف الغرز المنفذة .
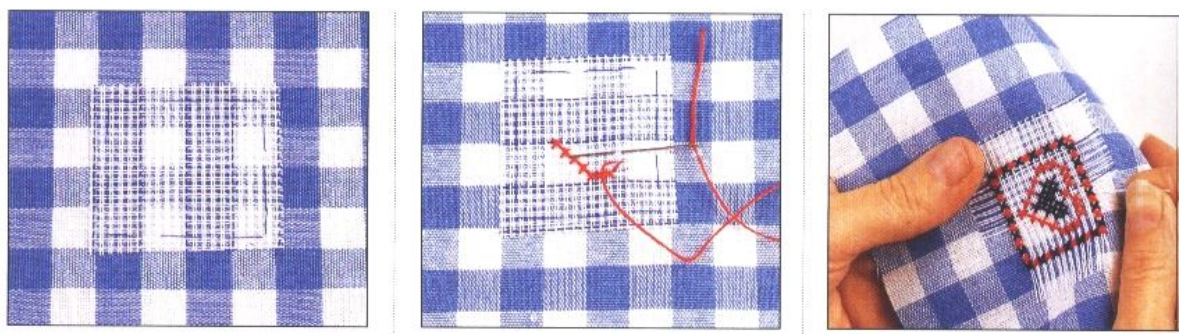

شكل رقم ( ) يوضح طريقة التنسيل (rv )

لذا هذه الطريقة تحتاج إلى مهارة عالية وإتقان عند التتسيل حتى لا يتشوه الشكل العام

للغرز بعد التتسيل. كما أنها تأخذ وقتا طويلا وخاصة إذا كانت الوحدات المطرزة كبيرة. ومن هنا كانت مشكلة البحث إيجاد حلول بديلة لعمل الغرز الخاصـة بقماش الإيتامين على القماش المنسوج بدون استخدام أسلوب تتسيل الإيتامين مع إعطاء تأتئير زتخرفية جميلة وقياس مدى تقبل المر أة العاملة لهذه النو عية من المكملات حيث أن المر أة بطبعها تميل إلى التجديد وتحتاج

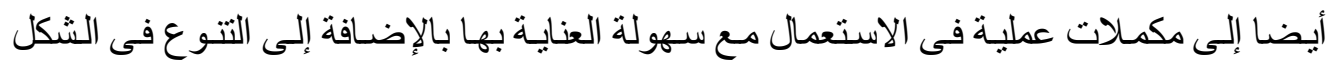
وتجميلها بأسلوب غير تقليدى.

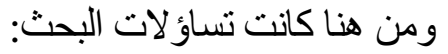

1. هل يمكن استخدام الايتامين لنقل تأثيرات الطباعة على القماش. r. هل يمكن تطريز التأثيرات الناتجة من استخدام الايتامين كوسيط لنقل الطباعة . r. هل يمكن انتاج مكملات من القطع الناتجة بعد الطباعة و التطريز. ع. هل تلائم القطع المنفذة المرأة العاملة.

أهداف الاراسة:Research Aims 1. إيجاد حل بديل لتتسيل الايتامين عند استخدامه فى التطريز على القماث. r. استخدام الايتامين كوسيط لنقل تأثئير ات الطباعة . 
r. .حقيق قيم جمالية ونفعية باستخدام الطباعة والتطريز على المكملات المصنعة من الأقششة. ؛. . دراسـة مدى تقبل المر أة العاملة لنو عيـة المكملات المنتجة من حيث (الاسلوب، التصميم الزخرفى، التطريز، الخامة، الناحية التسويقية والجمالية) .

\section{أهمية الدراسة: Research Importance}

ا ـ تتمية القدرة الفنية و التصميمية والتطبيقية لدى المهتمين بدر اسة الاشغال اليدوية. r. الاستفادة من هذه الدراسة فى زخرفة مكملات الملابس و إظهار ها بشكل جمالى مبنكر. r. الحصول على مكملات عملية فى الاستعمال مع سهولة العناية بها.

\section{فروض الدراسة:Research Assumptions}

1 . توجد علاقة ذات دلالة إحصائية بين الأسلوب المستخدم تقبل المر أة العاملة للمكملات المنفذة. r. توجد علاقة ذات دلالة إحصائية بين التصميم الزخرفى وتقبل المر أة العاملة للمكملات المنفذة.

r.. توجد علاقة ذات دلالة إحصائية بين التطريز وتقبل المر أة العاملة للمكملات الدنفذة. ع. توجد علاقة ذات دلالة إحصائية بين الخامة المستخدمة فى تتفيذ المكمل وتقبل المر أة العامله له. ○. توجد علاقة ذات دلالة إحصائية بين الناحية التسويقية وتقبل المر أة العاملة للمكملات المنفذة. T. توجد علاقة ذات دلالة إحصائية بين مكملات ملابس المنفذة بأسلوب الطباعة و التطريز باستخدام الإيتامين كوسيط و إثراء العمل الفني مما يعطى إحساسا جماليا يختلف عن الأساليب

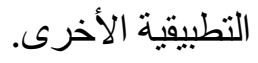

\section{حدود البحث:Research Limits}

$$
\text { نوعيــة : (أ) قماث الكتان لإنتاج المكملات }
$$

(ب) تصميمات زخرفية تصلح للطباعة بالاستتسل فيطن

(ج) أسلوب الطباعه بالاستتسل (استنسل - ألوان الطباعة)

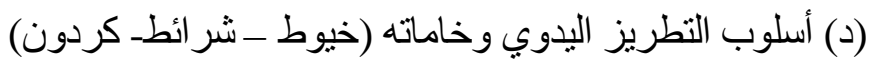

بشريــة: المر أة العاملة من مهن مختلفة لعرض المنتجات عليهم وتقييمها من خلال بنود الاستمارة. 
أدوات البحث : Research Tools

1. استمارة التقييم حيث تتكون من خمسة محاور وكل محور يشتمل على مجمو عة من البنود.

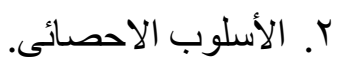

\section{منهج البحث:Research Curcumas}

المنهج التجريبي

1. . عرض الاستمارة على المحكمين من اساتذة الجامعة للحكم على البنود.

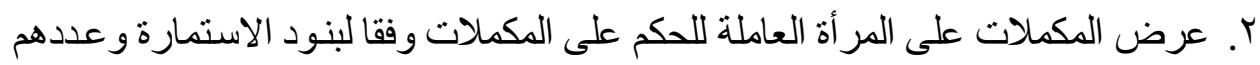

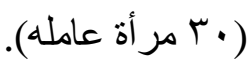

r. استخدام التحليل الاحصائى للوصول الى النتائج.

Research Idioms: مصطلحات البحث

الطباعــة: Printing

النقوشات السطحية أو زخرفة سطوح الأقشة باستخدام ألوان غير قابلة للذوبان في الماء

أو صبغات ثابتة فى تكوينات تكرارية منتظمة (؛').

Embroidery:التطريـز

اســ أعجمي اثــتق مـن الكلمـة الفارسية (طر ازيـدان) ويقابلهـا فـى اللغـة الإنجليزيـة

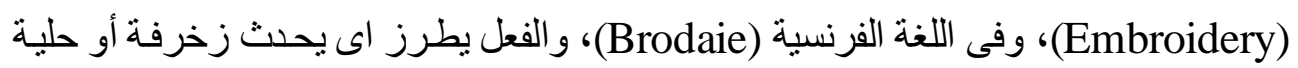

تطبق على هيئة مختارة من نسيج معين (10).

التصميم الزخرفى:The decorative design

هو ترجمة لموضوع معين بفكره مرسومة هادفة لها علاقة تامة بوسيلة التتفيذ وتحمل فى طياتها

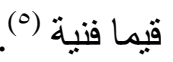

مكملات الزى: Accessories

ـ عبارة عن الكماليات التى تضاف لتحسين وتجميل المظهر فهى على سبيل المثال الحقائب و الأحزمة و القبعات والأحذية والقفاز ات و الكر افتات و الحلى ، أى انها الاشياء الثانوية التى قد

ترتدى مع الثياب و عادة لا يمكن الاستغناء عنها لانها تكمل المظهر الكلى للفرد ('). 
ـ مكملات الملابس عبارة عن قطع أو اضافات تصاحب الملبس الرئيسى وتعمل على زيادة تأثيره للوصول الى الاناقة، وقد أصبح لمكملات الملبس دور أ أساسيا فى انكال المظهر الملبسى للمرأة

حيث يعطيها مزيدا من التأنق ويبرز جمال ملبسها مهما كان بسيطا (").

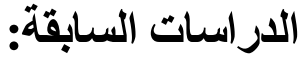

دراسة (1): نادية محمود خليل 1911 بعنوان" مكملات الملابس ودور ها كأحد مقومات الأناقة

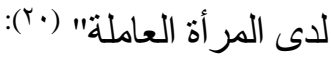

تهذف الدارسة إلى دراسة أنو اع مكملات الملابس المختلفة والتعرف على دور كل منها فى إضافة لمسات الجمال للملبس كذللك التعرف على افضل اسلاليب اختيار تلك المكملات وكيفية تو افقها مع الملابس بالإضافة الى خلق دو لاب ملابس اقتصادى للمر أة العاملة قو امـة الىى جانب الملابس قطع المكملات الملائمة.

وتوصلت الى أن استخدام مكملات الملابس لها دور فى تخفيض المنفق على الملابس كما ان

الاهتمام باختيار الملبس المناسب ومكملاته يؤثر على الراحة النفسية والثقة بالنفس لدى المر أة العاملة.

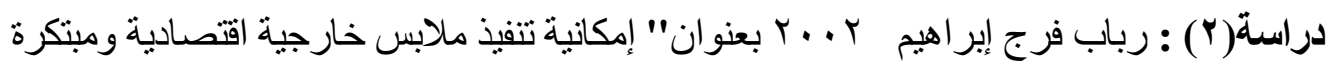
للمر أة باستخدام مكملات الملابس ومدى تأثير ها على المظهر الملبسى" (^): تهدف الدراسـة إلى توفير ملابس مبتكرة للمـرأة تعتمد على إضـافة المكمـلات بنو عيهـا (المتصلة ـ المنفصلة) وتوضيح الأساليب المستخدمة فى تتفيذ هذه النو عية من الملابس ومكملاتها للوصل الى مظهر مناسب وأنيق بالإضـافة الى ترشيد الإنفاق على ملابس المر أة الخارجية من خلال الاستخدام الامثل لمكملات الملابس بنو عيها.

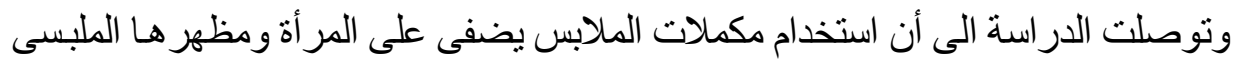
أناقة ورونقها وجمالا اذا استخدت بأسلوب فنى وذوق جميل وان استخدام مكملات الملابس مع الع الملبس يساعد كثير ا على ترشيد الاستهلاك عن طريق إمكانية الظهور بأكثر من مظهر أنيق باستخدام زى واحد بمساعدة المكملات.

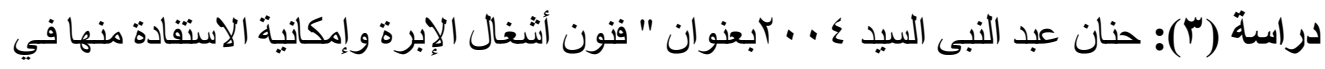

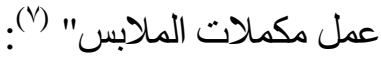


تهدف الدر اسة إلى اهتمام بفنون اثغال الابرة والاستفادة منها فى اثر اء جماليات مكمـلات

$$
\text { الملابس بما يحدم تصميم الازياء و اقتصاديات الاسرة . }
$$

وتوصلت الدراسة إلى أن أفضل فنون أثنال الإبرة المستخدمة فى عمل مكملات الملابس

هو التطريز ويتساوى معه الكروشيه الذى يتساوى معه أيضا التريكو.

دراسـة( ) : أمل بسيونى ، اسمهان إسماعيل T ج . ب بعنوان " الاستفادة من إمكانيات الطباعة

اليدوية بالثابلونات في رفع القيمة الفنية لمكملات ملابس السهرة للسيدات" (ع):

تهدف الدر اسة الى محاولة الاستفادة من اسلوب الطباعه بالثشابلونات في رفع القيمة الجمالية و الفنية لمكملات ملابس السهرة للسيدات وذلك للحصول على انماط فريدة تتسم بـالمظهر الانيق و المسايرة للعصر الحديث إلى جانب الاقتصاد فى التكلفة حيث اجريت الطباعة بهذه الطريقة لبعض المكمـلات المنفصلة لملابس السهرة للسيدات (شـالـ فيونكهـ شريط للر أس- حقيبة يد - حذاء) وللتأكد من مدى جودة هذه التطبيقات ثم عرضها على فئات مختلفة من المحكمين للاستبيان عن القيمة الفنية للطباعات ومدى تأثثر ها على اناقة المظهر الملبس العام. وتوصلت الدر اسة من خلال النتائج الإحصائية للاستبيان انسجام ألوان وخطوط الطباعات وتألفها مع خامة وشكل المكمل الملبسى بشكل متميز ومعاصر يحقق الثز اء فى القيمة الفنية مما ييشر بإمكانية تعميم استخدام منل هذه الطباعات مستقبليا بشكل ناجح و على نطاق و اسع. دراسة (0): صفاء محمد نعمان عبد الوهاب ع . . ب بعنو ان" تجميل الملابس بتصميمات زخرفية إسلامية مطبو عة ومطرزة بخامة عجينة السير اميك" (r'). وتهدف الدر اسة الى در اسة استخدام اسـاليب فنيـة قديمـة بطريقة فنية معاصرة وحديثة فى تصميم وتتفيذ مكملات الملابس بهدف احياء التراث الفنى و الكثف عن القيم الاصيلة فيه من خلال ـ دراسـة العناصـر الزخرفيـة المنسوجة والمطرزه فـى التراث المصرى القديم وتوظيفها فى ــ تصميمات زخرفية معاصرة لمكملات الملابس.

-در اسة اسلوبى الزخرفة النسجية والتطريز و الاستفادة منهما فى مجال مكملات الملابس - إبراز اسلوبى الزخرفة النسجية والتطريز فى تتفيذ مكملات للملابس تتسم بالقيم الجمالية. وتوصلت الدراسة الى أن الزخارف المستخدمة فى مكملات الملابس فى العصرين الفرعونى و الاسلامى لم تختلف عن الزخارف المستخدمة فى الفنون الاخرى من عناصر نباتيـة وهندسية 
وكتابية وكائنات حية وانه فى العصرين الفر عونى و الاسلامى استخدم فى تطريز مكملات الملابس اسلوبى الزخرفة النسجية و التطريز.

دراسة(†) : غادة شاكر عبد الفتاح عفيفى 1 +. ببعنوان" المزج بين طباعة المنسوجات والتطريز في تصميم أقششة المفروشات باستخدام بعض الأساليب التطبيقية الحديثة" (10) تهاف الدراسة إلى التجريب في تصميم وتقنيات المفروشات وذللك بالمزج بين اسلوبين جماليين هامين بالنسبة لأقشة المفروشات و هما طباعة المنسوجات و التطريز بحيث يعمل كل اسلوب كعنصر ا مكملا للآخر فى التصميم العام لاتتاج المجمو عات للمفروشـات، واستخدمت لهن الباحثة الوحدات البنائية الاسلامية فى محاولة لاحياء التراث الاسلامى وقد استخدم فى هذا البحث خامة القطن المخلوط بالبولى استر لانتاج مجموعات من المفروشات (ستائر ، قماش تتجيد، مفرش سفره، مفرش سرير ) وتم التنفيذ باستخدام الطباعة بالشابلونات اليدويـة و الميكانيكية و التطريز الالى لأفضل مجموعة تصميمية بناء على استمار ات الاستبيان التي تم عن طريقها تحكيم التصميمات واختيار أفضل مجموعة للتنفيذ اتفق عليها المحكمون ـ

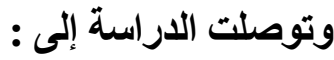
- إمكانية المزج بين اسلوبى الطباعة و التطريز لتجميل الدفروشات .

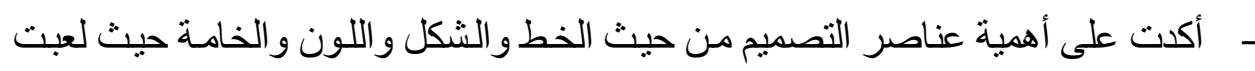
دورا هاما في إبراز جماليات التصميم فتوفرت فيه كل الدقومات المؤدية إلى نجاحه ميع مر اعاة الأسس الواجب إتباعها عند إنتاج تصميم جيد مثل التوازن والتناسب و الإيقاع

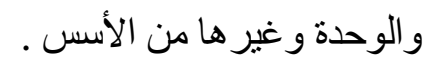

\section{واستفادة الباحثة من هذه الاراسات فيما يلى:}

ا . التعرف على انواع مكملات الملابس المختلفة وأهميتها بالنسبة للمر أة العاملة.

$$
\begin{aligned}
& \text { r. للمكملات دور ا كبير ا فى ترشيد الاستهلاك. } \\
& \text { r. أهية اشغال الابرة وبخاصة التطريز. }
\end{aligned}
$$

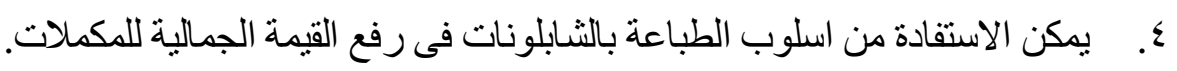
0. امكانية دمج اسلوبى الطباعة والتطريز لزخرفة المفروشات. 
محاور البحث ونتناول فيه :

1- الأقشثة المستخمة فى تتفيذ المنتج ( الايتامين لنقل تأثيرات الطباعة ) ـ الكتان في تتفيذ المكملت .

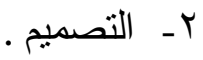

r- أساليب زخرفة المكملات أ ـ الطباعة بالاستنسل ب ـ الخامات المستخدمة في التطريز

$$
\text { ع ـ ـ المكملات المنفذة . }
$$

أولا :الأقششة المستخدمة في التفيذ ( الايتامين لنقل تأثثرات الطباعة )ـ الكتان في تثفيذ المكملات .

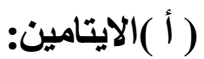

هو قماث قوى ذو نسيج مفتوح يستخدم فى اطار التطريز بـالإبرة، ويعنى فى القاموس

القبب او الخيش وقد وجد علماء الاثار بقايا قطع مطرزة من هذا النوع فى مصر و الصين وبلاد

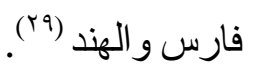

و هو يتكون من عدد من الخيوط الرأسية (خيوط السداء) تتقاطع عموديـا مع عدد من الخيوط الافقية (خيوط اللحمة) و هى متوفرة فى طرز نسجية متعددة و ابعاد متعددة وهى باحجام يتوقف على عدد الخيوط فى البوصسه وكلمـاز الت عدد الخيوط فـى البوصـه كلمـا كانت الغرز المشغولة صغيرة. أما الوان الايتامين فمعظم الايتامين من اللون الابيض، وممكن أن يكون بـاللون الاسود، وبعضه باللون البيج و المظلل باللون الخوصى أى اللون الاحمر المصفر، والايتامين من الكتان او القطن تكون سهلة الصناعة و انعم ملمسا (^^) .

Fabrics (ب) (بأقمشة

مصطلح يطلق على جميع الاقشة المنتجة بالوسائل المختلفة مثل (المنسوجات و التريكو و اللياد) (1') .وقد تم استخدام قماش الكتان فى تتفيذ المكملات .

\section{الأقمشة المناسبة للتطريز:}

لكل عمل من اعمال التطريز نوع خاص به من الاقمشة التى تصلح له، فالتطريز بغرزة الظل يحتاج الى قماش شفاف نوعاو التطريز بغرزة الايتامين او (Cross Stitch) يحتاج الى 
قماش الايتامين (Aida) بفتحاته المتفاوته الحجم ولكن يمكن اعتبار ان الاقمشة القطنية الخالصة المتماسكة ذات المسام الضيقة وذات النقل المتوسط و الاتيال و الكتان (اللينن) هى أنسب الأقمشة

$$
\begin{aligned}
& \text { للتطريز اليدوي (17) } \\
& \text { ثانيا : التصمـيم نوعــــان: }
\end{aligned}
$$

\section{التصميم البنائى: Structure Design}

و هو يتضمن الخطوط البنائية المكونة للثئ المر اد تصميمه وتظهر أهمية هذا النوع من التصميم فى اختبار ونرتيب العناصر الداخلة فى التصميم من خطوطو أثنكال وألوان ومساحات

$$
\text { وذللك تبعا للأسس الفنية المختلفة (IV'). }
$$

\section{التصميم الزخرفى: Decorative Design}

وهو يتعلق بتزيين وتعديل البناء، ليكون اكثر تأثير الى جانب انه يضيف أهمية جاذبية

$$
\text { للشئ المراد زخرفته (r) (1). }
$$

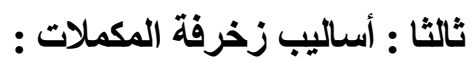

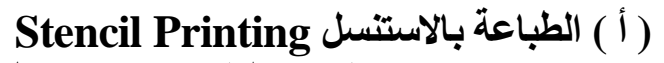

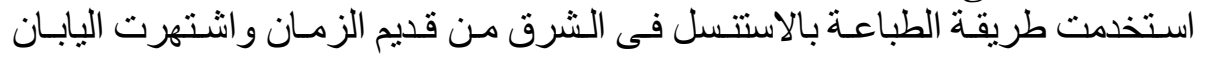
بمطبو عاتها الجميلة بهذه الطريقة، وتقوم الطباعة بالاستتسل على تفريغ الزخارف على ورق مقوى لا ينفذ منه اللون ولا يتشرب به لأن الغرض من استعمال هذا الورق هو عزل الصبغة عن القماث ولهذا تغطى الاماكن التي لا ير اد تلوينها، أمام الأماكن التي تفرغ فهي المساحات التى تطبع بألو ان الصبغة المختلفة، وتمتاز طريقة الاستتسل بالسهولة وقلة التكاليف كما انها تعطى زخارف دقيقة من الوان متعددة وبدرجات لونية مختلفة.

ولتلـوين الامـاكن المفرغـة تـستعمل فرشـاة المـق وذللك بوضـع معجون اللـون على لوح زجاجى ويغمس المدق فى معجون اللون وينقل منه الى القماش على أن يدق بالفرشـاه راسيا حتى لا

تلخخل شعيرات الفرشاه تحت اطر اف حافة الفتحات فتلون الاماكن غير المرغوب فى تلوينها (؟). ( ب ) الخامات المستخدمة فى التطريز وغرز التطريز : الخيــوط: Threads

تتميز خيوط التطريز بتعدد خاماتها و الو انها وانو اعها فهى تتتاسب مع مختلف الخامات ويسهل الاختيار بين هذه الأنواع بما يتناسب مـع الخامـة وشكل ونوع الوحدة الزخرفيـة المراد 
تتفيذها، وقد تطورت خيوط التطريز تبعا لتطور النسيج فبعد انتاج خيوط قطنية وكتانية وصوفية وحريرية ظهرت الالياف الصناعية المحورة كالفسكوز و الاستياب و الالياف الصناعية التركيبية مثل البولى استر والنايلون فظهرت تبعا لذلك الخيوط التركيبية المطاطة والخيوط المخلوطة حتى تنتلاءم مع النسيج المنتج (9)

Cord: الكــــردون

يصنع من الخيوط اللامعه وهو عبارة عن حبل رفيع من عدة خيوط مزوية او مجدولة مـع

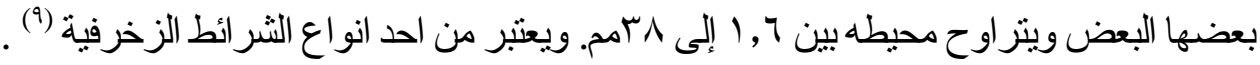

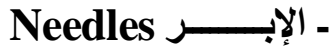

تتنوع الابر من حيث سمكها وطولها وحجم العين (التقب) وكذللك من حيث شكل سنها أو خامتها، واختبار الإبر يعتمد على النسيج وكذلك أنواع الغرز وسمك الخيطويجب أن تكون الإبرة مصنو عة مـن صـنف جيد لا يصدأ وحسادة أو تكون مطليـة بـالبلاتين لسهولة عمليـة السحب و الاحتكالك أثناء العمل ولكل إبرة رقم وهذا الرقم يدل على الحجم فكلمـا زاد الرقم كلمـا اعطيت ابره سميكة وكلما قل الرقم أعطت إبرة رفيعة. يوجد الان العديد من الابر - وكل واحدة منها ملائمة لوظيفة خاصة_ فعند اختيار الابرة من المهم الأخذ فى الاعتبار كل اعمالها. و أنها سوف تؤثر على جودة المظهر والثكل النهائى كما يتم اختيار الابرة تبعا للخيط المستخدم وكذلك القماث (1^). ـ الغرز المستخدمة في الدراسة التطبيقية :

ا ـ غرزة الصليب (الغرزة المتقاطعه) Cross Stitch: هى واحدة من الغرز الاساسية فى التطريز بالابرة ولها العديد من الاشكال لأنها تصنع غرزنين متقاطعتين تغطى مربع من الكنفاه او الايتامين (·r).

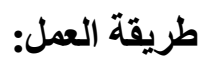
'. تغرز الإبرة من اليسار إلى اليمين من أسفل إلى أعلى بغرزة مائلة ويكرر العمل تبعـا لصد الغرز المطلوبة 
80 RASHA EL- GOHARY

Y. نعود مره أخرى من اليمين إلى اليسار بشكل مائل بنفس الطريقة السابقة ولكن بعكس اتجـاه

الغرز السابقة (1') - (1)
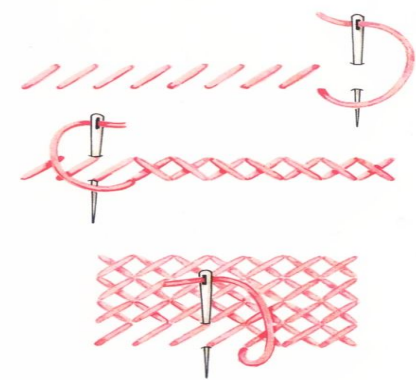

شكل رقم (Y) يوضح غرزة الصليب (·)

r- الغرزة المثقاطعة سميرنا Stitch:

I. نشتغل غرزة متقاطعة على شكل X

r. . بنفس المكان وفوق الغرزة السابقة تشتغل غرزة أخرى على شكل +، ويكرر العمل لباقي

الغرز

r. يكون استخدام عدد الخيوط تبعا لسعة الغرزة وحسب الرغبة فى تكبير ها ويمكن استخدام

الثر ائط (كردون) بديلا للخيط مع هذه الغرزة (17')

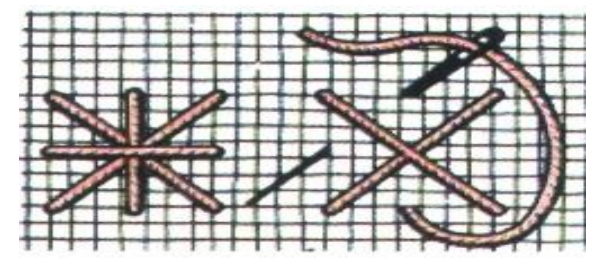

شكل رقم (Y) يوضح الغرزة المتقاطعة سميرنا (17 )

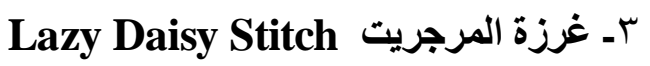

هى غرزة سلسلة معزولة (مفردة) تستخدم دائمسا لتطريز أوراق الزهر وأوراق الشجر الصغيرة.

غرزة السلسلة تثبت بغرزة منفرجة صغيرة (·.). 
طريقة العمل : - مل

ا. نبدأ بتنبيت الغرزة من داخل الزهرة، ثم تخرج على مسافة طول ورقة الزهرة بغرزة

$$
\text { السلسلة على أن يكون الخيط ور اء الابرة. }
$$

Y. تغرز الإبرة في نهاية الورقة مباثرة لتنبيتها ثم اخرجيها من بداية الورقة التالية (1').
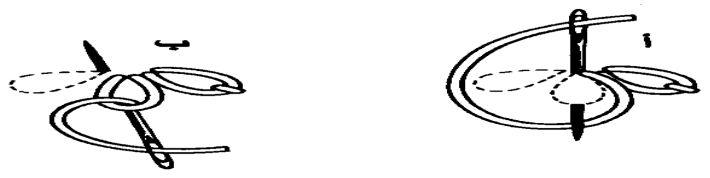

شكل رقم (ع) يوضح غرزة المرجريت (17)

عـ غرزة الحشو المتداخل (الستان) Long And Short Stitch

تملأ هذه الغرزة المساحات الكبيرة نوعاو التى لا تغطيها غرزة الحشو، وهى من الغرز

$$
\text { الجميلة لعمل الزهور والأوراق (17). }
$$

تتفذ بنفس الطريقة الحشو بالر غم من أن المظهر النهائى مختلف كليا (rV). طريقة عمل:

'. تغرز الإبرة من أعلى إلى أسفل كما هو الأمر فى غرزة الحشو، إلا أن الاختلاف يكون

بعمل غرزة طو يلة وأخرى قصيرة متلاصقة، وذللك تبعا لحجم الرسمة. ץ. . يكمل الجزء السفلى من الرسم وذللك بغرزة الابرة من أعلى إلى أسفل كذللك بنفس الثقوب

$$
\text { الناتجة عن الغرز السابقة فى السطر العلوى. }
$$

r. يمكن عمل سطر ثالث بنفس الطريقة لتعبئة المساحة المر اد تطريز هـا، مـع ملاحظة ان

تكون الغرز على شكل شعاع ينطلق من مركز الزهرة (17').

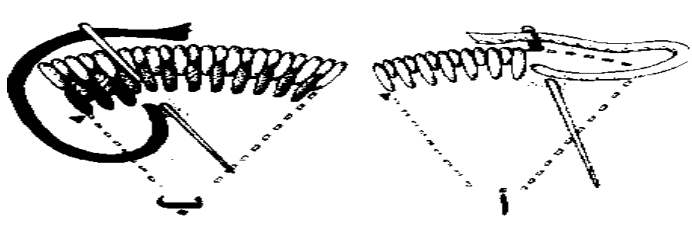

شكل رقم(ه) يوضح غرزة الحشو المتداخل (11) 
هـ غرزة الترمسـه: Button Hole Wheel

و هى نفس طريقة عمل غرزة الفستون ولكن الاختلاف أنها تعمل من نقطة واحدة فى المركز

فيظهر تقب في المنتصف وتأخذ شكل الدوائر والزهرة الدستنيرة أو حول دائرة مستنبرة (VV).

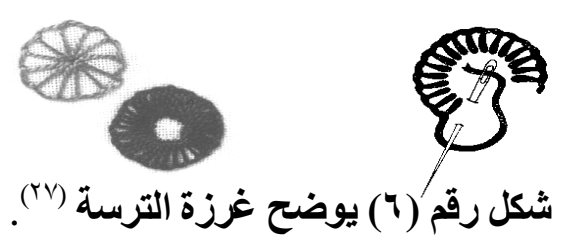

דا غرزة الركوكو Bullion Knot

استخدام إبرة طويلة مع ثقب (عين )صغيرة لعمل غرزة الركوكو

1. يثبت الخيط فى ظهر النسيج، وتدخل الإبرة من الأمام على بعد نصف سم من مكان

خروجها، أو حسب الطول المطلوب للغرزة ثم تخرج من الأمام بنفس تقب أول غرزة دون

ان تسحب من القماث.

r. . يلف الخيط حول سن الابرة البارز عدد من اللفات تكون مساوية لطول الجزء المختفي من

الإبرة، وفى نفس الوقت المحافظة على تسلسل لفات الخيط بوضع ابهام اليد اليسرى عليها

$$
\text { كى لا تتسرب اللفات من سن الابرة ثانية. }
$$

r. اسحبي الإبرة من الخيوط الملفوفة بحذر و اغرزيها فى نفس مكان دخول الابرة في النسيج.

ع. نتنبه بأن لا نترك الخيوط الملفوفة من تحت الابهام قبل خروج الإبرة ('1").

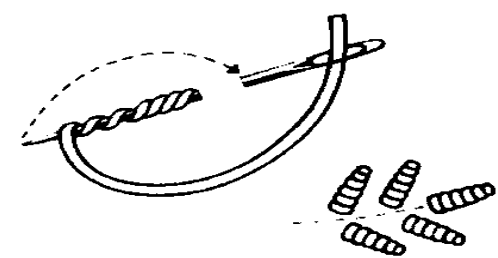

شكل رقم (V) يوضح غرزة الركوكو (11)

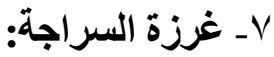

ا . تستخدم إبرة رفيعة كى لا تؤثر على مسام النسيج، ويعقد طرف الخيط فى البداية 
r. يدأ من اليمين إلى اليسار بعمل غرز متساوية فى الطول أو أن تكون احداها قصبرة و الأخرى طويلة، مع ملاحظة عمل مجمو عة كبيرة من الغرز فى نفس الخطوة قبل سحب

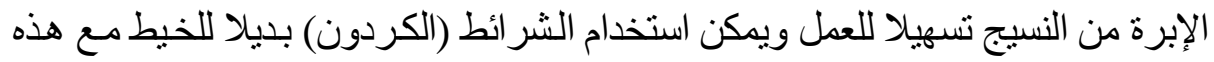
الغرزة (17).

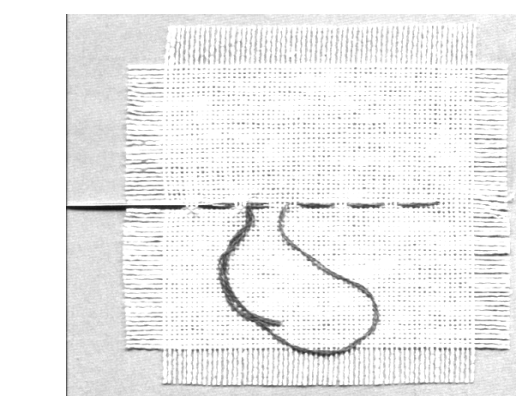

شكل رقم (^) يوضح غززة السراجة (11)

رابعا : أنواع المكملات المنفذة :

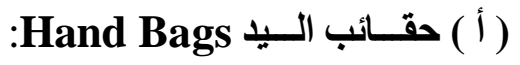

الحقيية هى جزء هام من المظهر الخارجى للفرد وهى من المكملات الاساسية التى لا

تستغنى عنها المرأة وعند اختيار الحقيبة يراعى أن يؤخذ فى الاعتبار حجمها ، شكلها، لونها، خامتها والمناسبة التى ترتدى فيها لأن كل عنصر من هذه العناصر يمكن ان يؤثر ايجاييا أو سلبيا على المظهر الملبسى للفرد و لا شك أن اثكال وخامات و ألوان الحقائب تختلف من وقت لآن لآخر تبعا للموضة السائدة حيث تخضع الحقائب لعمليات التجديد و الابتكار فى تصميمها شأنها فى ذلك شأن الملابس.

وقد تكون الحقائب ذات يد طويلة تحمل على الأكتاف او بدون يد وعادة ما تفضل المرأة العاملة الحقائب ذات اليد الطويلة وهى أكثر مناسبة للفترة الصباحية وير اعى ألا تكون يد الحقيبة طويلة تصل إلى الأرداف. ويمكن استخدام الحقيبة الكبيرة نوعا فى الفترة الصباحية اثناء العمل مع مر اعاة ان يتتاسب حجمها مع حاملتها، فالمر أة المثلئة يجب أن لا تحمل حقيبة صغيرة حتى لا تبدو كالمر اهقة او لهائ حقية ضخمة حتى لاتزيدها ضخامه، و انما يمكنها استخدام حقيبة ذات حجم مناسب. 
وتصنع الحقائب من خامـات منتو عة كالجلد (طبيعى ـصناعى) ، أو القماث (الكتان-

القطيفةـ الستان)، أو البلاستيك، أو القش والحبال المكرمية (ج).

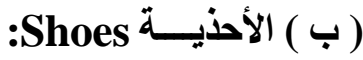

تعد من المكملات الهامة لاستكمال اناقة الفرد، ويعد شر اء الحذاء من أهم قرارات الشراء التى نتخذها، حيث تمثل لنا الر احة فى الحركة والسير، كنلك يجب مر اعاة الحقة عند اختبار الحذاء، لأن الأحذية قد تشوه مظهر الفرد ويحثث نلك غالبا إذا لم تكن ملائمة للمناسبة التى ترتدى فيها، لذا أن تبدو الأحنية منر ابطة فى خطوطهاو ألو انها وخاماتها مع الملابس المرتداه منها. وتتتوع الأحذية تبعا لاستخداماتها، فمنها مـا يناسب فترة الصباح ومنها مـا هو خاص بفترات ما بعد الظهر، وما هو خاص بالمساء و السهرة كما انها تصنع من خامـات متعددة منها الجلد و الثمو اه و القماش (r).

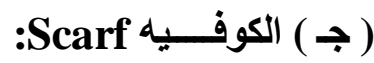

كلمة إيطالية استعار ها أهل الثرق الذين كانوا يمارسون التجارة فى الموانى المصرية

$$
\text { و السورية فى القرون الوسطى (1). }
$$

و هى قطعة قماش مستطيلة تستخدم لتغطية الكتفين و الجزء العلوى من الجسم (ء ().

$$
\text { الخامات المستخدمة في البحث : }
$$

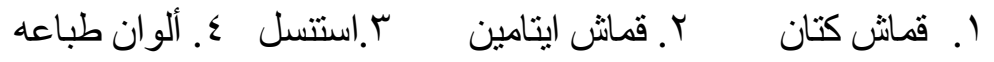

$$
\text { ع. خيوط تطريز (كتون بارليه) بألو ان مختلفة + كردون + ابر تطريز }
$$

0. تصميمات زخرفية تصلح للطباعة بالاستتسل

7. أدوات تجهيز الاستتسل (كربون للطباعه، آله حادة لتقريغ الاستتسل)

خطوات تنفيذ الاطقم والتقييم :

' ـ تحديد المنتجات التي سوف تتفذ (حقية يد، حذاء أو سابوه، كوفيه)

$$
\text { r. اعداد باترون للمنتجات (المكملات) التى سوف تتفذ }
$$

"؟. شر اء الخامات اللازمة وهى قماش كتان لتنفيذ المكملات و المو اد المساعدة وهى الايتامين . الاستنسل. الألوان. فرش للألون او قطعة إسفنج، خيوط وشر ائط التطريز، كردون. 
ع. قص قماش الكتان ليصلح لكل من حقبة اليد والحذاء أو السابوه والكوفيه وكنلك قص قماش

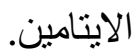
๑. تحديد التصميم الذي سوف ينفذ ويتفق مع المنتج. 7. . طباعة التصميم على الاستتسل

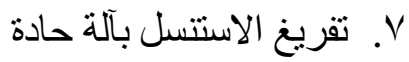
^. تحديد الألوان التي سوف ينم الطباعة بها. 9 9. طباعة التصميم بالألوان المحددة على قماش الكتان على أن يكون قماش الايتامين بين

الاستتسل المفرغ وقماش الكتان.كما هو موضح بالثكل رقم (9)

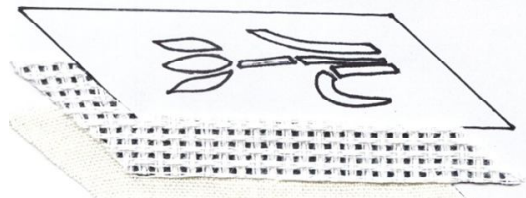

شكل رقم (9) يوضح أسلوب الطباعة باستخدام الايتامين كوسيط

• ا. تحديد الغرز المستخدمة في التطريز. 11. تحديد الخيوط أو الثر ائط و ألو انها للقيام بعملية التطريز r ا. القيام بتطريز المكملات. با. . خياطة المكملات و إعدادها للشكل النهائي. ع ا. إعداد استمارة لتقييم المنتجات (المكملات). 
جول رقم \} 1 يوضح المنتجات المنفذة ومواصفاتها

\begin{tabular}{|c|c|c|}
\hline مواصفات المنتج & المنتــــج & مسلسل \\
\hline 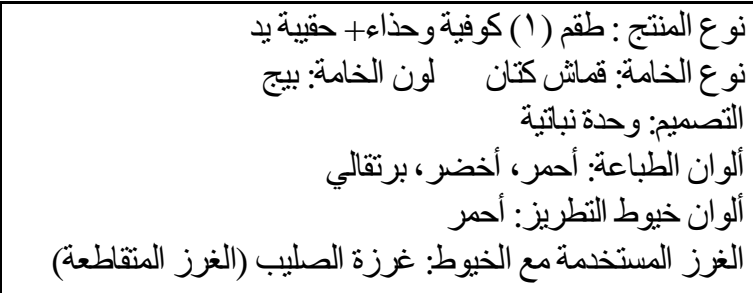 & & 1 \\
\hline 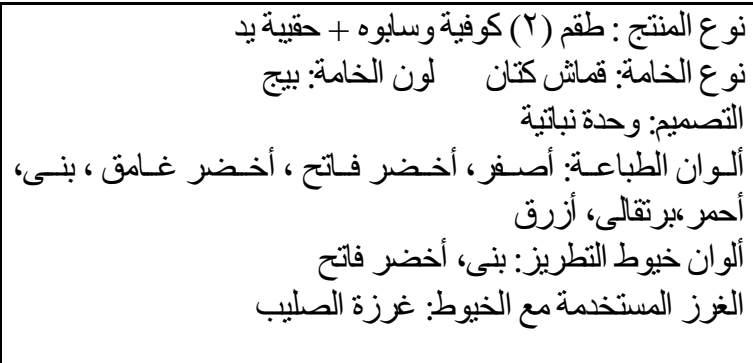 & &.$r$ \\
\hline 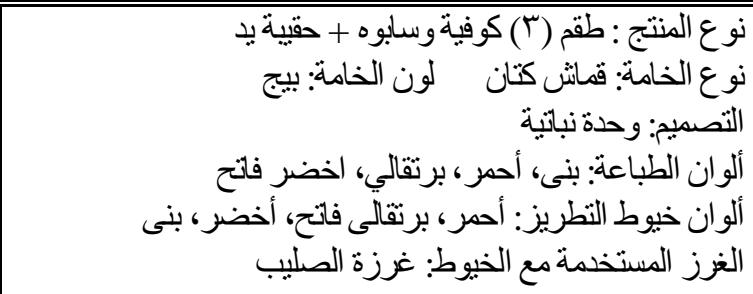 & & $r$ \\
\hline 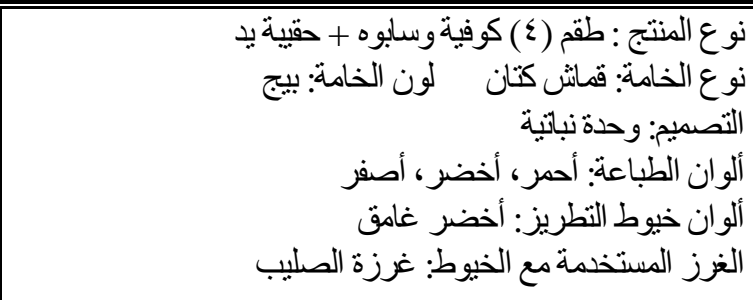 & &.$\varepsilon$ \\
\hline 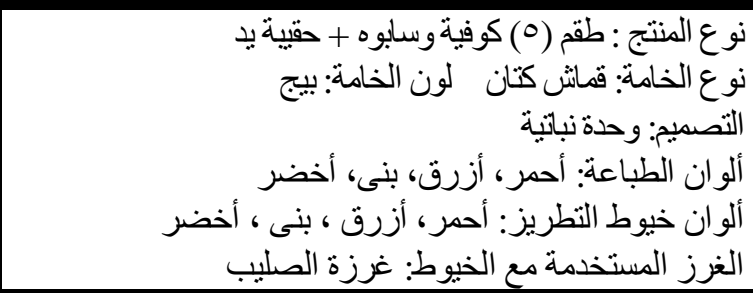 & & .0 \\
\hline
\end{tabular}




\begin{tabular}{|c|c|c|}
\hline مواصفات المنتج & i & مسلسل \\
\hline 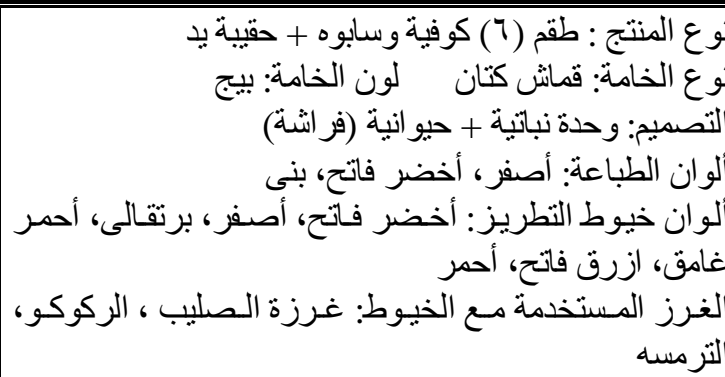 & & .7 \\
\hline 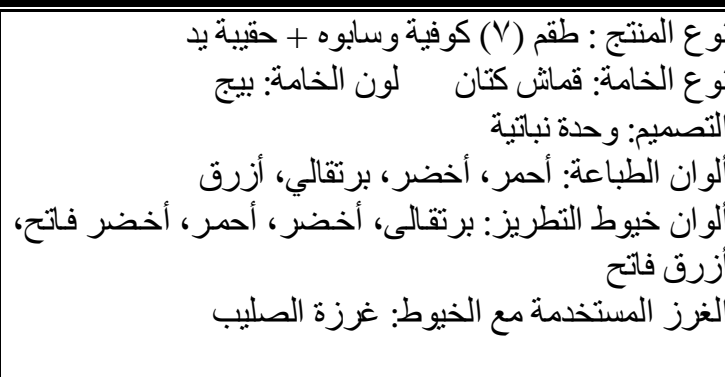 & &.$V$ \\
\hline 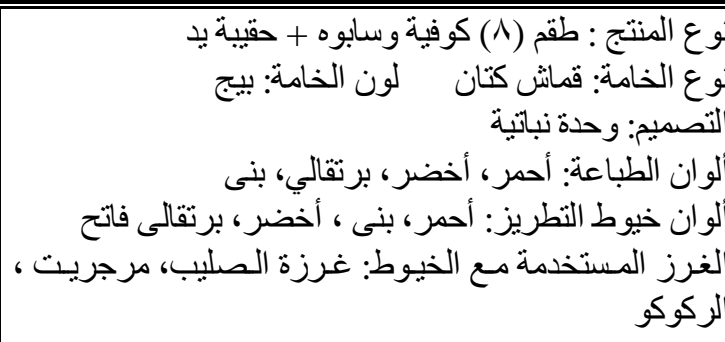 & &.$\wedge$ \\
\hline 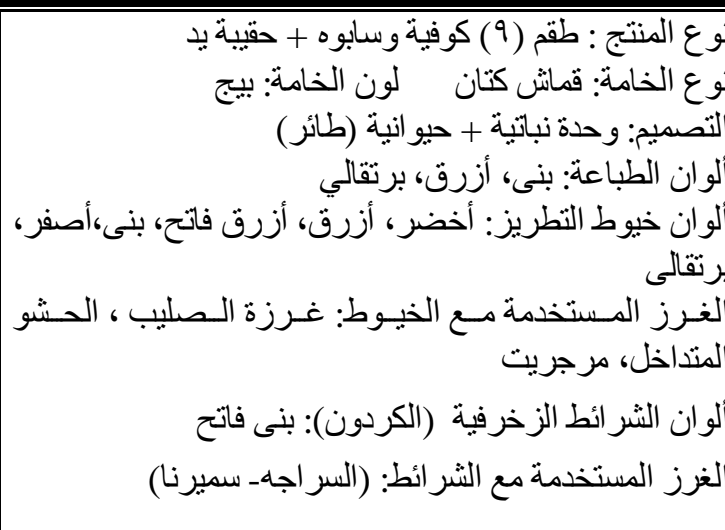 & 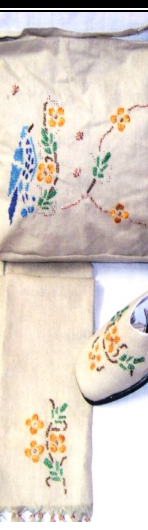 & .9 \\
\hline
\end{tabular}




\begin{tabular}{|c|c|c|}
\hline مواصفات المنتج & المنتــــج & مسلسل \\
\hline 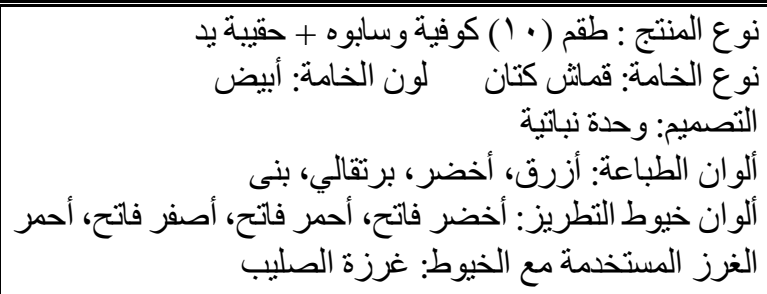 & & 1 . \\
\hline 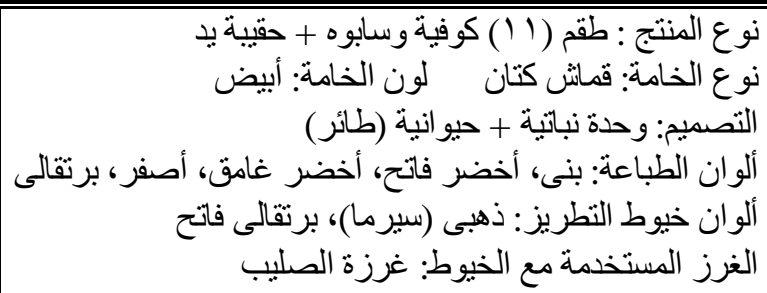 & & .11 \\
\hline 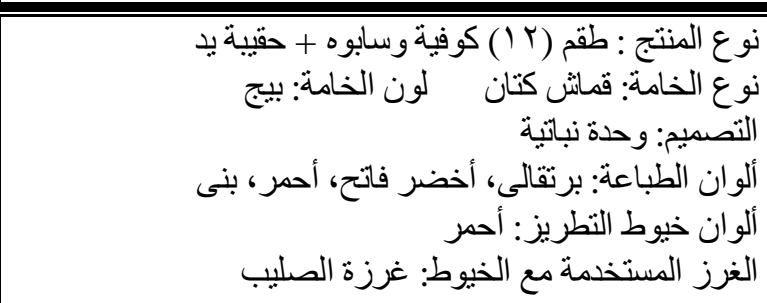 & & $.1 T$ \\
\hline
\end{tabular}

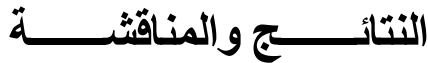

- يص الفرض الأول على : توجد علاقة ذات دلالة إحصائية بين الأسلوب المستخدم وتقبل

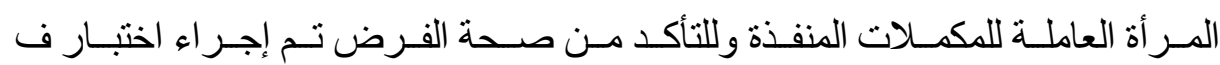

(F) المحسوبة وحساب المتوسط كما هو موضح بالجدول رقم (Y) وشكل رقم ( • () . 
جدول رقم \}

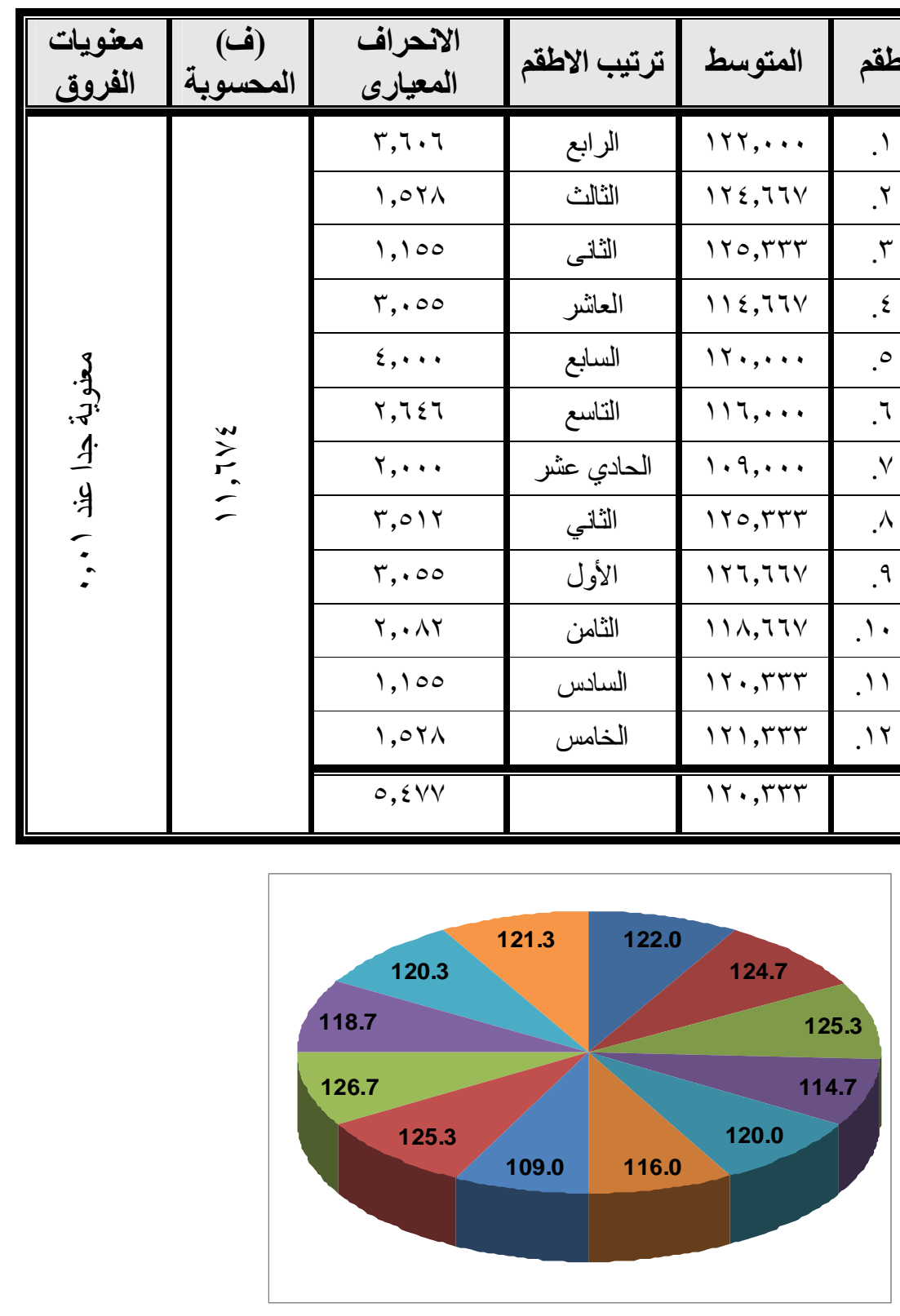

شكل رقم ( • (1) يوضح متوسطدرجات تقييم المحكين للأطقم بالنسبة للأسلوب 
تبين من النتائج فى جدول رقم (Y) وشكل رقم ( • (1) أن متوسط الطقم التاسع بلغ نحو

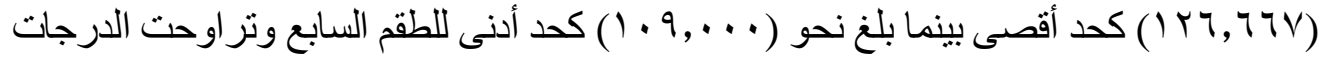
المنوسطة لباقى الأطقم بينهم، حيث كان ترتيب الأطقم من حيث الأسلوب و وقا لآراء المرأة العاملة

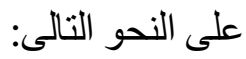
\} الطقم التاسع-( الطقم الثالث و الثامن) تساووا فى درجة التقييم - الطق الثانىــ الطقم الأولـ- الطقم الثانى عشر - الطقم الحادي عشر - الطقم الخامس - الطقم العانشر - (الطقم السادس- الطقم الزابعالطقم السابع \{، و على الجانب الآخر تراوحت قيمة الانحر اف المعيارى ما بين ( . ., ؛) كحد

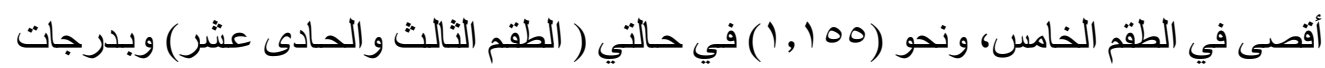

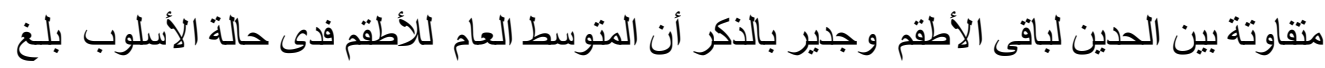

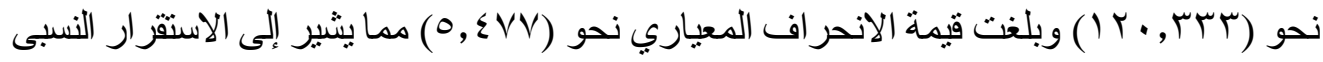

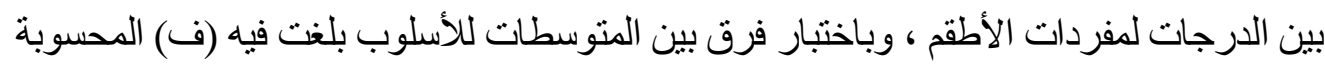

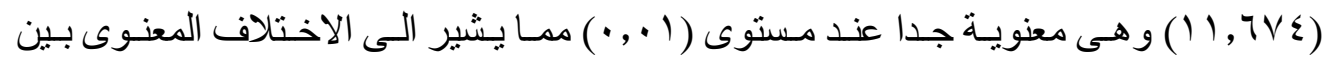

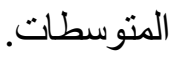

يتضح ان أسلوب نقل تأثيرات الطباعة باستخدام الايتـامين على قماث الكتان وتطريزة وجد استحسان من قبل المر اه العاملة وخاصة مع الطقم التاسع الذى حصل على الترتيب الأول يليه بافي

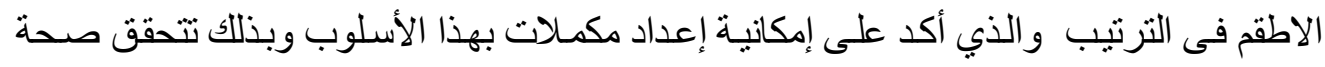

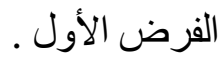
ـ ينص الفرض الثاني على : توجد علاقة ذات دلالة إحصائية بين التصميم الزخرفى المستخدم وتقبل المر اة العاملة للمكملات المنفذة وللتأكد من صحة الفرض نم إجراء اختبار ف (F) المحسوبة الفية

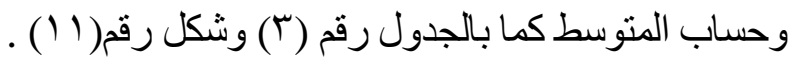




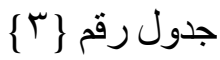

\begin{tabular}{|c|c|c|c|c|c|c|}
\hline الفروق & المصسوبة & الالمعياري & ترثيب الأطقم & المتوسط & الأطقم & المقارنة \\
\hline \multirow{13}{*}{$\begin{array}{l}\frac{3}{3} \\
: \frac{3}{4} \\
\frac{1}{4}\end{array}$} & \multirow{13}{*}{$w_{w}^{>}$} & $\varepsilon, 994$ & الثناني & $T r \varepsilon, V O$. & 1. & \multirow{12}{*}{ 司 } \\
\hline & & $r, 701$ & الخامس & $119, \ldots$ &.$r$ & \\
\hline & & $r, 7 r q$ & الساس & $111, \mathrm{ro}^{\circ}$ & $r$ & \\
\hline & & $\Gamma, \mu \cdot \Sigma$ & العانثر & $1.1, \vee 0$. & $\varepsilon$ & \\
\hline & & $0, V M V$ & الثامن & $11 \mathrm{~V}, \mathrm{YO}$. & 0 & \\
\hline & & r,Trq & التاسع & $117,80$. & .7 & \\
\hline & & $Y, V \cdot \Lambda$ & الحادي عشر & $1 \ldots, \ldots$ & $v^{\prime}$ & \\
\hline & & $r, \leqslant 17$ & الأولَ & ITV,0.. &.$\wedge$ & \\
\hline & & $1, \varepsilon 1 \varepsilon$ & الثالث & 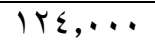 & .9 & \\
\hline & & $\cdot, 90 \mathrm{~V}$ & السابع & $11 \mathrm{~V}, \mathrm{VO} \ldots$ & 1. & \\
\hline & & $1, V \cdot \Lambda$ & الرابع & $|Y|, V O$. & 11 & \\
\hline & & $r, 7 r q$ & السابع & $11 \mathrm{~V}, \mathrm{VO}$. & IT & \\
\hline & & $V, 7 \wedge 0$ & & $11 \mathrm{~V}, \mathrm{~V} 9 \mathrm{r}$ & & المتوسط العلم \\
\hline
\end{tabular}

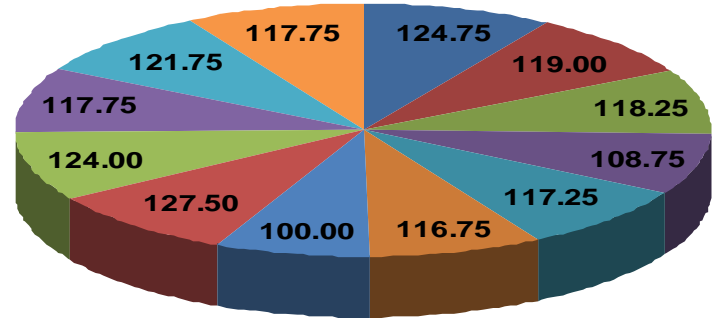

شكل رقم ( 11 ) يوضح متوسط درجات تقييم المحكمين للأطقم بالنسبة للتصميم الزخرفى

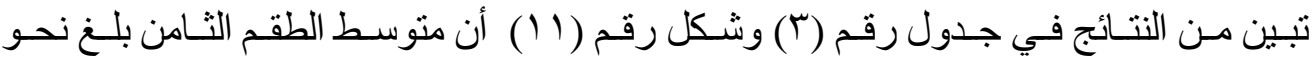

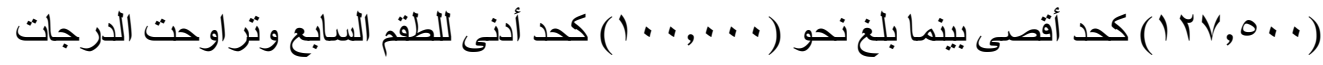
المتوسطة لباقى الأطق بينهم، حيث كان ترتيب الأطقم من حيث التصميم وفقا لآر اء المر أة العاملة

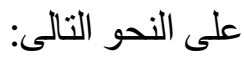
\} الطقم الثامنـ الطقم الأولـ الطقم الثاسع ـ الطقم الحادى عثر ـ الطقم الثانى ـ الطقم الثالث ـ الأطقم ( العانثر و الثانى عثر) نساووا فى درجة التقييم ـ الطقم الخامس- الطقم الساس- الطقم الرابع ـ الطقم

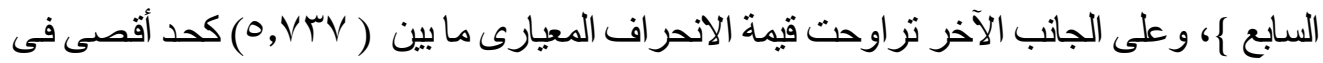
الطقم الخام،، ونحو (90V , •) فى حالة ( الطقم العانشر) وبدرجات متفاوتة بين الحسين لباقى الأطقم 


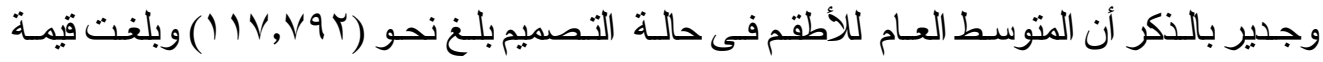
الانحراف المعيارى نحو (V, Y100) مما يثير إلى الاستقرار النسبى بين الدرجات لمفردات الأطقم ، وباختبار الفروق بين المتوسطات للتصميم بلغت فيه (ف) المحسوبة (Vـ ـ , • Y) وهى معنوية جدا عند مستوى ( ا . , ) مما يثير الى الاختلاف المنوى بين الكتوسطات. يتضح مما سبق ان ملاءمة التصميم الزخرفى من حيث المساحة واللون والشكل ووجود انسجام وتو افق بين ألوان الطباعة المستخدمة جعت الطقم الثامن في المرتبة الأولى ويليه باقي الاطقم وبذلك تتحقق صحة الفرض الثاني . ـ ينص الفرض الثالث على : توجد علاقة ذات دلالة إحصائية بين التطريز المستخدم وتقبل المرأة

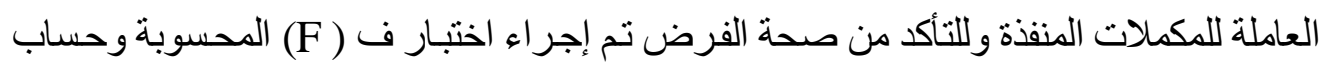
المتوسط كما بالجدول رقم (乏) وشكل رقم(r I ) .

جدول رقم \}؛

\begin{tabular}{|c|c|c|c|c|c|c|}
\hline الفروق & المحسوبة & الالمعرافي & تزتيب الأطقم & المتوسط & الأطق & المقارنة \\
\hline \multirow{13}{*}{ 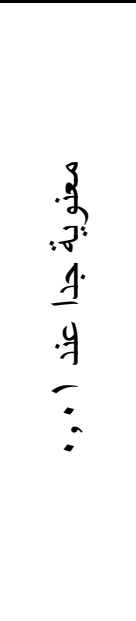 } & \multirow{13}{*}{$\begin{array}{l}\frac{2}{\sigma} \\
=\end{array}$} & r,qvo & الساس & $11 \wedge, 7 \ldots$ & & \multirow{12}{*}{ 司 } \\
\hline & & r, & الخامس & $119, \varepsilon \ldots$ &.$T$ & \\
\hline & & $r, 910$ & السابع & $11 \wedge, \ldots$ &.$r$ & \\
\hline & & $\varepsilon, Y \vee A$ & العاثر & $111,7 \ldots$ &.$\varepsilon$ & \\
\hline & & $r, 0.9$ & الخامس & $119, \Sigma \ldots$ & .0 & \\
\hline & & $r, \leq Y)$ & التاسع & $\| \leq, Y \ldots$ & .7 & \\
\hline & & $r, . \leq q$ & الحادي عشر & $1 \cdot v, 7 \ldots$ &. $\mathrm{V}$ & \\
\hline & & $1, \Gamma \cdot \varepsilon$ & الثناني & $\mid Y, Y, \ldots$ &.$\wedge$ & \\
\hline & & $1,1 \leq$. & الأول & Iro, E. & .9 & \\
\hline & & r,977 & الثالث & 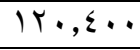 & 1. & \\
\hline & & $\varepsilon, \cdot Y O$ & الز ابع & $I_{\mu}, r_{*}$ & 11 & \\
\hline & & $r, 17 \Lambda$ & الثامن & $117, Y \ldots$ & IT & \\
\hline & & $0, \pi{ }_{1}$ & & $\| \vee, \neg \wedge \mu$ & & المتوسط العلم \\
\hline
\end{tabular}




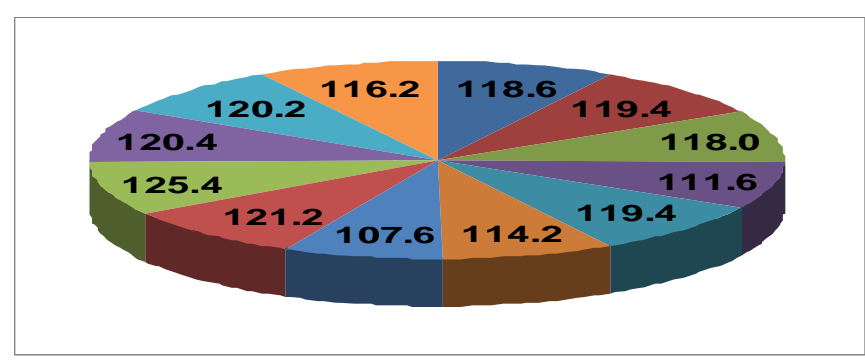

شكل رقم ( Y I ) يوضح متوسط درجات تقييم المحكمين للأطقم بالنسبة للتطريز

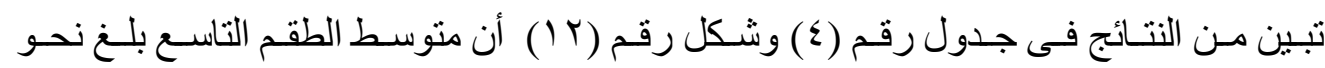

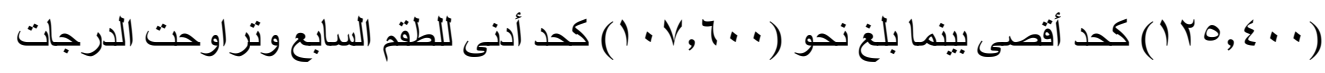
المتوسطة لباقى الأطقم بينهم، حيث كان ترتيب الأطقم من حيث التطريز وفقا لآر اء المر أة العاملة على النحو التالى: \} الطقم التاسعـ الطقم الثامنـ الطقم العاثر - الطقم الحادى عثر -( الطقم الثانى، الخامس) تساووا فى درجـة التقييم ـ الطقم الأولـ الطقم الثالثـ الطقم الثانى عشر ـ الطقم السادــ الطقم الرابعـ الطقم

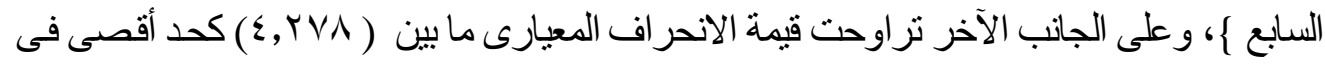
الطقم الرابع، ونحو ( • ع ( 1 ) فى حالة ( الطقم التاسع) وبدرجات متفاوتة بين الحدين لباقي الأطقم

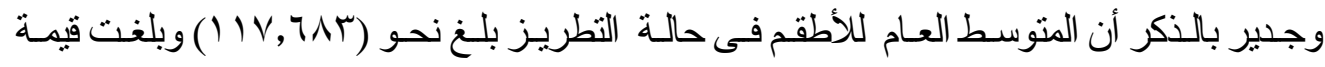
الانحراف المعياري نحو (اسM,0) مما يثير إلى الاستقرار النسبي بين الدرجات لمفردات الأطقم ، وباختبار الفروق بين المتوسطات النطريز بلغت فيه (ف) المحسوبة (r (1, I () و هى محنوية جدا عند مستوى ( ا + , · ) مما بشير الى الاختلاف المعنوى بين المتوسطات. يتضح ممـا سبق إن إجـادة اختيـار الخيوط المستخدمة مـع كـل مـن الطباعـة بالاستتسل والغـرز المستخدمة وقماث الكتان مع ملاعمة الغرز المستخدمة مع قماش الكتان ووجود انسجام وتو افق بين الو ان خيوط التطريز وألوان الطباعة جعلت الطقم التاسع في المرتبة الأولى يليه باقي الأطقم وذلك يثبت صحة الفرض الثاني . مان.

- ينص الفرض الرابع على : توجد علاقة ذات دلالة إحصائية بين الخامـة المستخدمة وتقبل المر أة العاملة للمكملات المنفذة وللتأكد من صحة الفرض تم إجر اء اختبار ف (F) المحسوبة وحساب المتوسط كما بالجدول رقم (0) وشكل رقم(r ( ) . 
جدول رقم

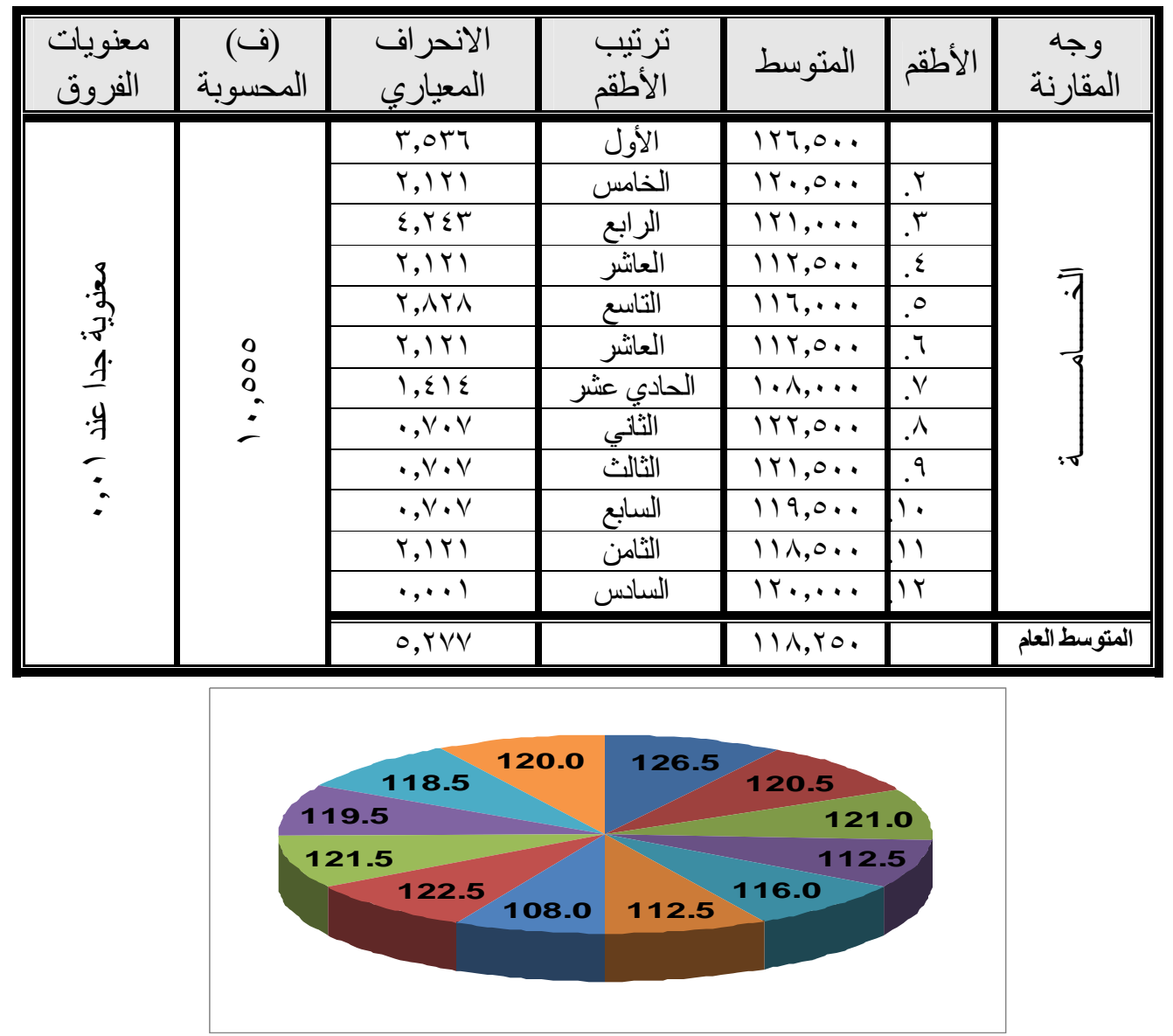

شكل رقم ( M I ) يوضح متوسط درجات تقيم المحكمين للأطقم بالنسبة للخامة

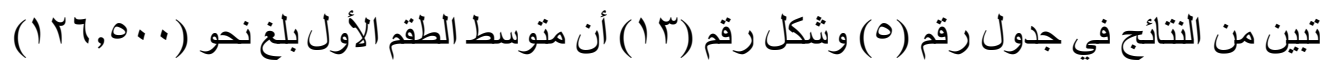
كحد أقصى بينما بلغ نحو ( . . . . • ( ) كحد أدنى للطقم السابع وتراوحت الدرجات المتوسطة لباقى الأطقم بينهم، حيث كان ترتيب الأطق من حيث الخامة وفقا لآر اء المر أة العاملة على النحو التالى: \} الطقم الأولـ الطقم الثامنـ الطقم التاسع ـ الطقم الثالثــ الطقم الثناني ـ الطقم الثاني عشر ــ الطقم العاثر - الطقم الحادي عشر - الطقم الخامس ( الأطقم الرابع والساد) تساووا في درجة التقييم -

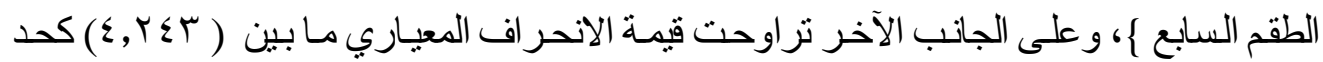
أقصى في الطقم الثالث، ونحو ( ( . . · ) فى حالة ( الطقم الثاني عشر) وبدرجات متفاوتة بين الحلين 


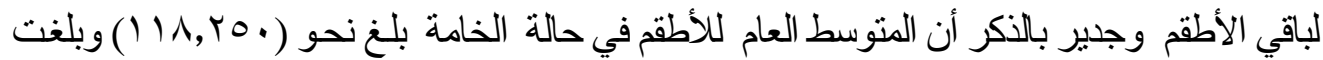
قيمـة الانحر اف المعيـاري نحو (0, YVV) ممـا يشير إلى الاستقرار النسبي ببين الدرجات لمفردات الأطقم ، وباختبـار الفروق ببين المتوسطات الخامسة بلغت فيسه (ف) المحسوبة (000, • () وهى معنوية جدا عند مستوى ( ا . , ) مما يشير إلى الاختلاف المعنوي بين المتوسطات. يتضح مما سبق أن خامة الكتان المستخدمة في إعداد المكمـلات لاقت استحسان من قبل المر أة العاملة وذلك يرجع إلى ملاءمة خامة الكتان لطباعة الاستتسل والتطريز و إعداد المكملات مع ملاحظة تصميم المكمل نفسه مما جعل الطقم الأول يحصل على الترتيب الأول يليه باقي الاطقم في الترتيب وبذلك يتحقق صحة الفرض الرابع . ـ ينص الفرض الخامس على : توجد علاقة ذات دلالة إحصائية بين الناحية التسويقية وتقبل المرأة العاملة للمكملات المنفذة وللتأكد من صحة الفرض تم إجراء اختبار ف (F) المحسوبة وحساب المتوسط كما بالجدول رقم (T) وشكل رقم(ع ا ) .

جدول رقم \}'

\begin{tabular}{|c|c|c|c|c|c|c|}
\hline الفروق & المحسوبة (ف) & الانحرياري & ترنيب & المتوسط & الأطق & المقارنة \\
\hline \multirow{13}{*}{3} & \multirow{13}{*}{$\sigma$} & $\varepsilon, O V T$ & الثالث & ITr,YO. & & \multirow{12}{*}{ 司 } \\
\hline & & $r, \ldots$ & الرابع & $|r|, 0 \ldots$ & .1 & \\
\hline & & $1, r q$. & الخامس & $K_{1}, 0 \ldots$ & 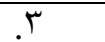 & \\
\hline & & $0, \varepsilon \leqslant V$ & الحادي عشر & $1.9,0 \ldots$ &.$\varepsilon$ & \\
\hline & & $r, 701$ & العانثر & $117, \ldots$ & .0 & \\
\hline & & $\varepsilon, \cdot \leq 1$ & السابع & $11 \wedge, 0 \ldots$ & .7 & \\
\hline & & $r, 9 \leq \varepsilon$ & الثاني عشر & $1, r, \ldots$ &.$V$ & \\
\hline & & $\varepsilon, Y \cdot r$ & الأَول & $1 Y 0,0 \ldots$ &.$\wedge$ & \\
\hline & & $r, 7 r q$ & الثاني & I Y $\leqslant, Y O$. & .9 & \\
\hline & & T,VAT & التاسع & $117,0 \ldots$ & 1. & \\
\hline & & $r, 7 \leqslant 7$ & السادس & $119,0 \ldots$ & 11 & \\
\hline & & $\varepsilon, \cdot \varepsilon 1$ & الثامن & $11 V, 0 \ldots$ & Ir & \\
\hline & & $V, 1 \leq 0$ & & $11 V, \wedge \vee 0$ & & المتوسط \\
\hline
\end{tabular}




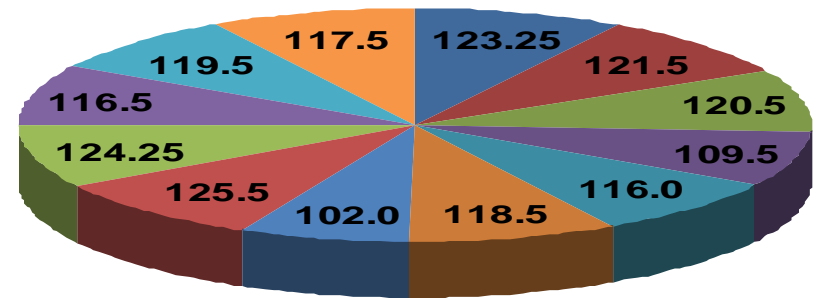

شكل رقم ( ع () يوضح متوسطدرجات تقييم المحكمين للأطقم بالنسبة للتسويق

تبين مـن النتائج فـى جدول رقم (7) وشكل رقم (ع () أن متوسط الطقم الثامن بلـغ نحسو

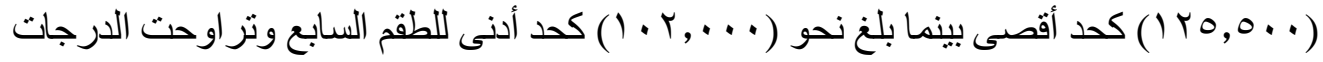
المتوسطة لباقي الأطقم بينهم، حيث كان ترتيب الأطقم من حيث التسويق وفقا لآراء المرأة العاملة

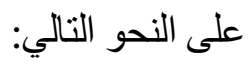

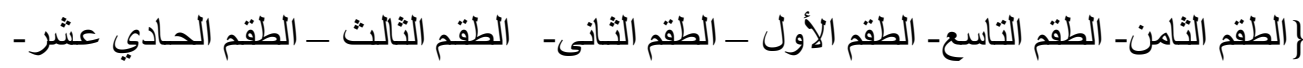
الطقم الساد ـ الطقم الثاني عشر ـ الطقم العانشر - الطقم الخامس ـ الطقم السابع ج؛ وعلى الجانب الآخر تراوحت قيمة الانحر اف المعيارى ما بين (

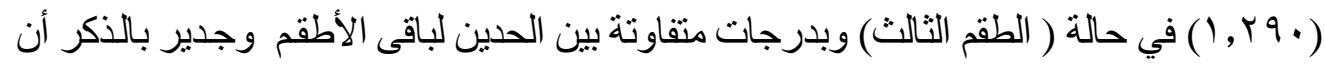

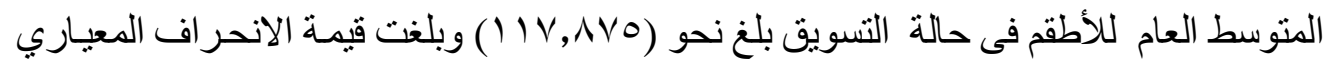

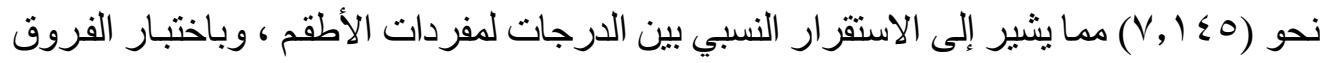
بين متوسطات الخامة بلغت فيه (ف) المحسوبة نحو ( . . , , . وهى معنوية جدا عند مستوى ( ( . • ) مما يشير إلى الاختلاف المعنوي بين المنوسطات.

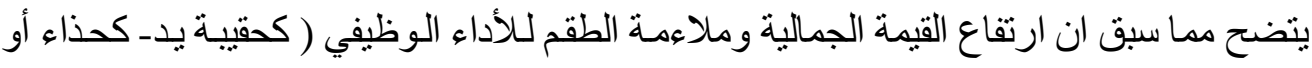
كسابوه - ككوفية)مع ملاعمته للمر أه العاملة جعلت الطقم الثامن في الترتيب الأول من حيث إمكانية

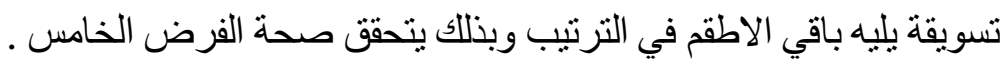
ـ ينص الفرض الساس على : توجد علاقة ذات دلالة إحصائية بين مكملات ملابس المنفذة بأسلوب الطباعة والتطريز باستخدام الإيتامين كوسيط و إثراء العمل الفني مما بعطى إحساسا جماليا

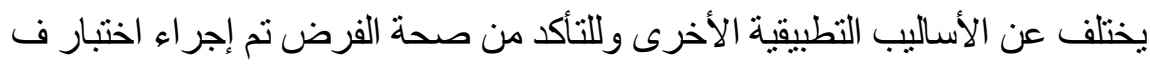

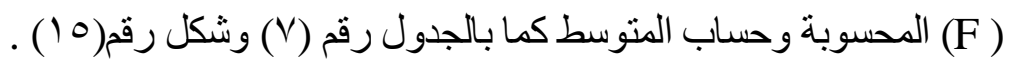




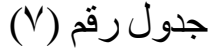

\begin{tabular}{|c|c|c|}
\hline الترتيب & اجمالى التقييم & الأطق \\
\hline الثالث & $710,1 \ldots$ & 1 \\
\hline الربع & $7.0, .7 \mathrm{~V}$ & $r$ \\
\hline الخامس & $T \cdot r, . \Delta r$ & r \\
\hline الحادي عشر & $00 \mathrm{~V}, .1 \mathrm{~V}$ & $\varepsilon$ \\
\hline التاسع & $0 \wedge \Lambda, 70$. & 0 \\
\hline العاثر & OVY,q0. & .7 \\
\hline الثاني عشر & 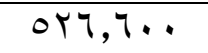 &.$V$ \\
\hline الأُول & TYY,.KT &.$\wedge$ \\
\hline الثاني & $T Y, \Lambda I V$ & .9 \\
\hline السابع & $09 Y, \wedge I V$ & . \\
\hline السادس & T..,YAK & 1 \\
\hline الثامن & OQY,VAT & Ir \\
\hline
\end{tabular}

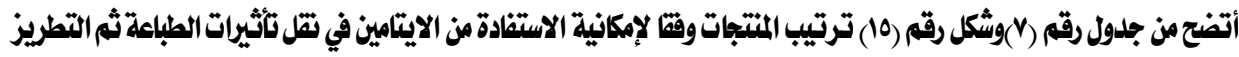
على قماش الكتان واستخدام المتتع في إعداد مكملات الملابس من وجهة نظر المرأة الكالملة على النحو التالى:

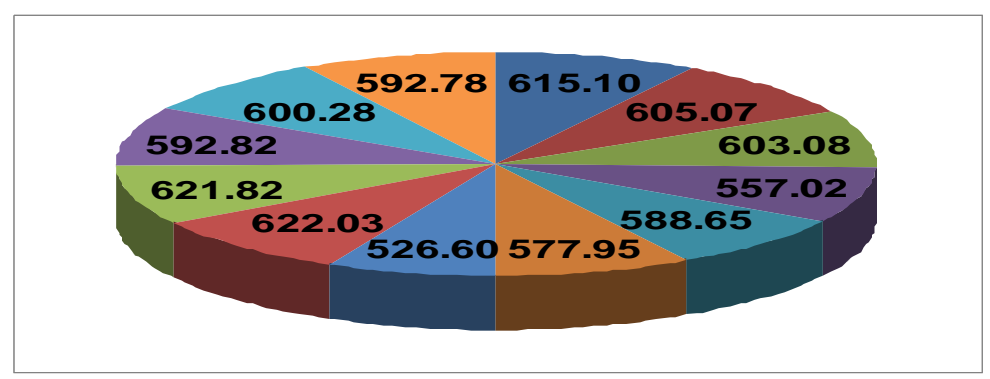

شكل رقم ( 10 ) يوضح متوسط درجات تقييم المحمين للأطقم

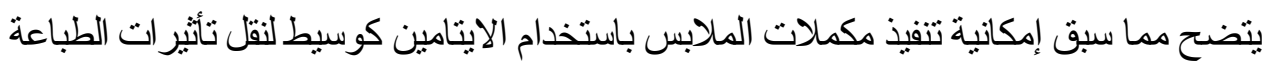
على القماش ثم تطريز ها بغرز الايتامين والغرز الأخرى بديلا عن التتسيل وذللك بالاختيار الجيد

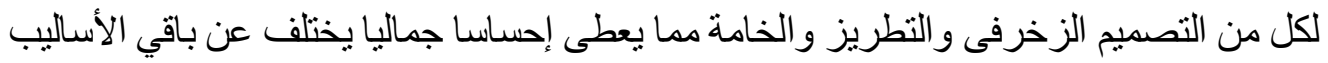

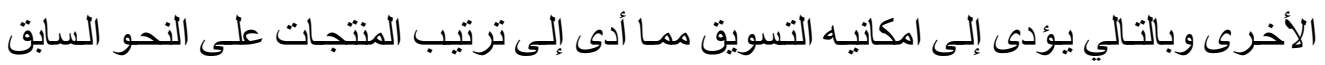
وحصول الطقم الثامن على الترتيب الأول يليه باقي الأطقم . 


\section{ملخص التنتائســــــ}

( .أكدت الدر اسـة على إمكانيـة الاستفادة من قمـاش الايتامين كوسيط للطباعـه على الكتان ثم . تطريزه بالإضافة إلى إمكانية تحويل المنتج المنفذ إلى مكملات تصلح للمر أة العاملة.

ץ. جاء ترتيب أفضلية ثلاثة من المنتجات من وجهة نظر المر أه العاملة نتيجة الاستنيان على النحو التالي الطقم الثامن يليه الطقم التاسع ثم الطقم الأول .

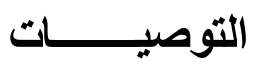

1. الاستفادة من إمكانيات خامة الايتامين في إيجاد حلول تتشكيلية متعددة للمكملات. Y. استخدام التقنيات المتعددة للطباعة اليدوية في تجميل مكملات الملابس. r. محاولة الاقتصاد في تكلفة مكملات الملابس للسبدات دون الإقلال من جودتها. ع. تشجيع طالبـات كليـة التربيـة النوعيـة والكليات المناظرة على الإبداع في مجـال مكمـلات الملابس واستغلالها في عمل صناعات صغيرة. ๑. تظيم دورات تدريبية في مجال مكملات الملابس باستخدام خامات وأساليب أخرى مختلفة. 


\section{ملحق (1)}

استمارة تقييم الطقم رقم ( ( ) ملحق )

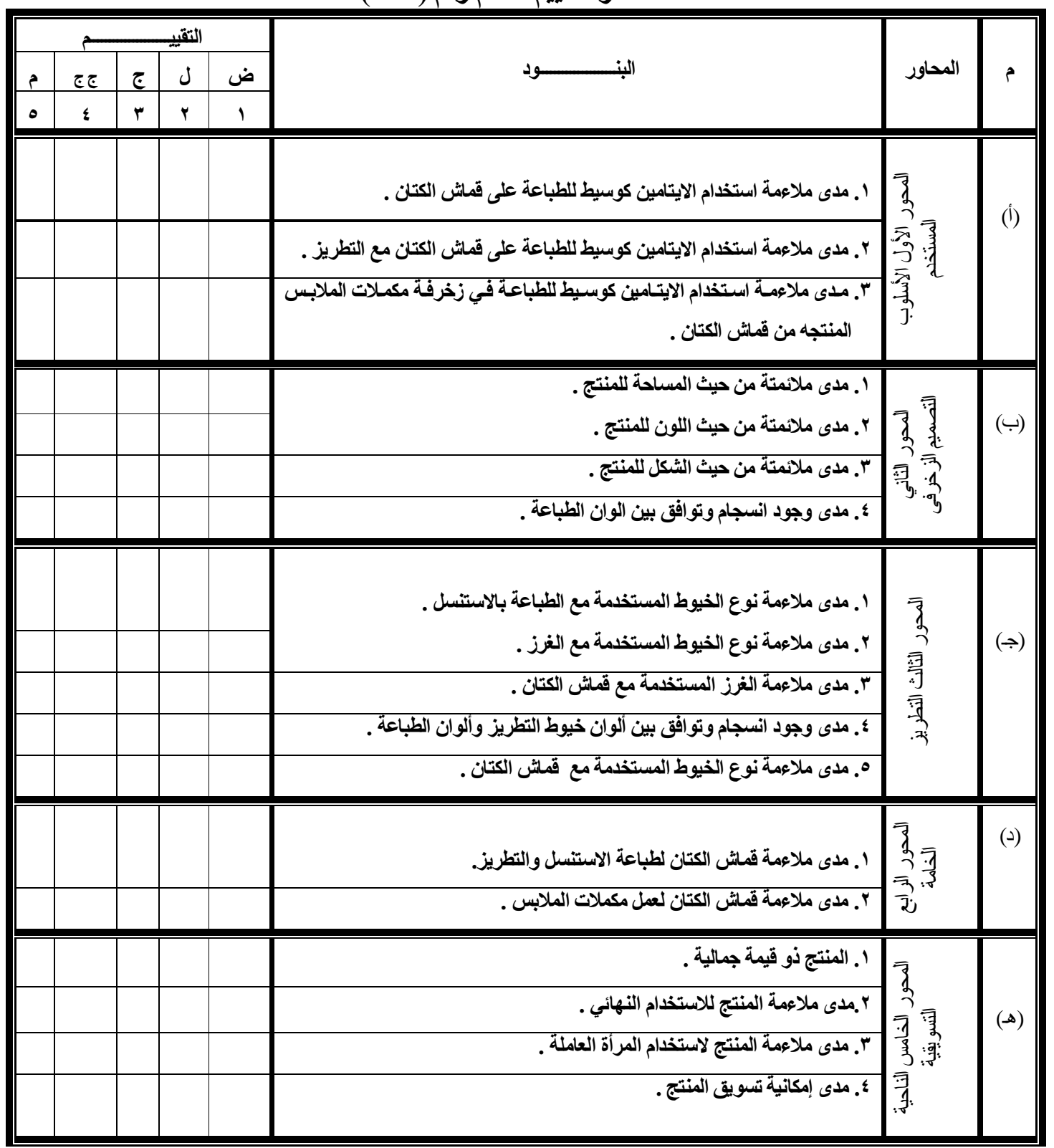




\section{ملحق (r)}

أسماء السادة المحكمين النين قاموا بتحكيم بنود الاستمارة

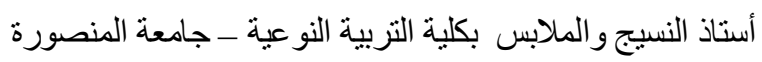
ا ـ أ.د/ على السيد زلط

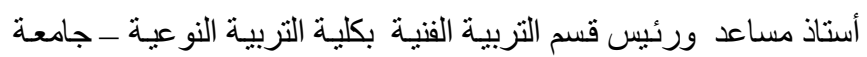
ا ب أ.م.د/ هانى عبده عبده قتتايه

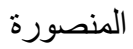

أستاذ مساعد الغزل و النسيج بقسم التزبية الفنية ـ كلية التريية النوعية ـ-

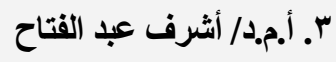

جامعة المنصورة مدرس أشغال فنية بكلية التربية النوعية - جامعة المنصورة

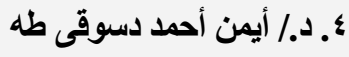

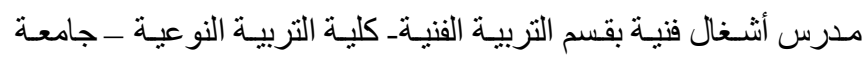

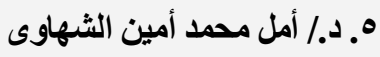
المنصورة مدرس تصميم بقسم التربية الفنية- بكلية التربية النو عية - جامعة المنصورة

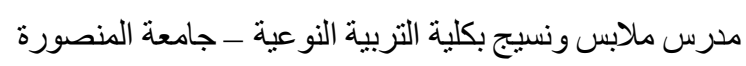
مدرس النسيج بكلية التربية النو عية - جامعة المنصورة

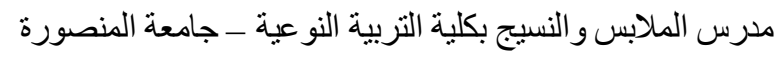

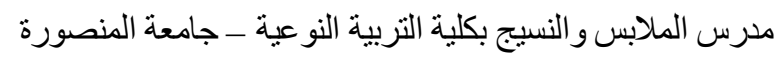
مدرس الملابس و النسيج بكلية التربية النو عية - جامعة المنصورة النية

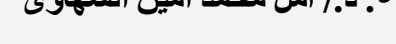

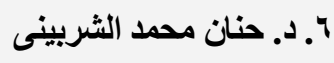

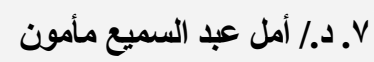

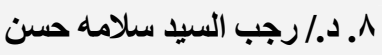

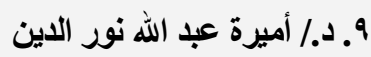

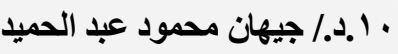

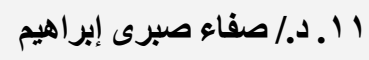

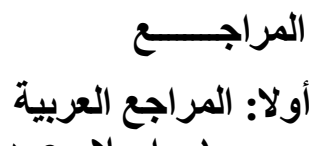

1. إسـلام عبد المنعم عبد الله حسين :" الاعتبـارات الوظيفيـة لأليـاف الحريـر الطييعي

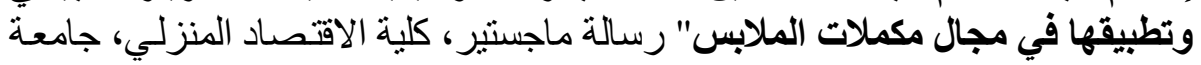

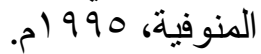

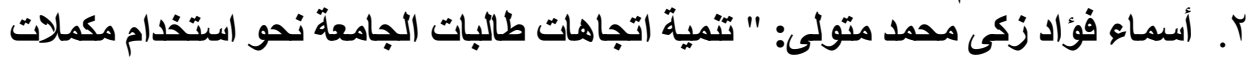

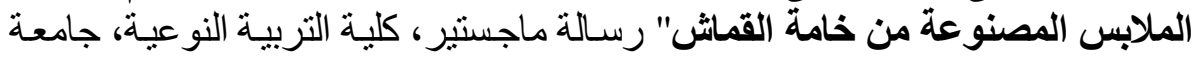

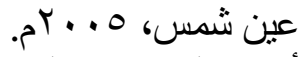

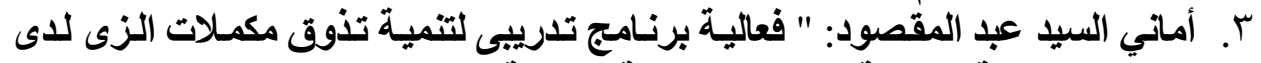

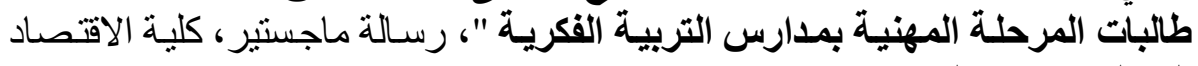

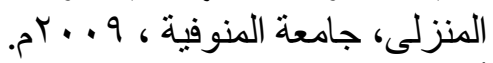

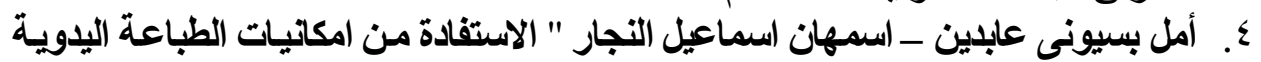

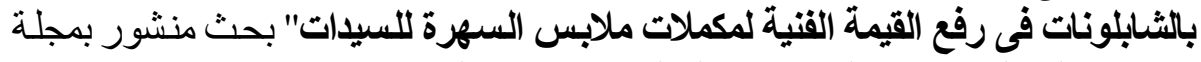

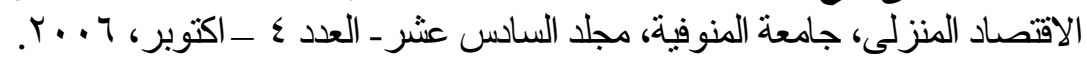




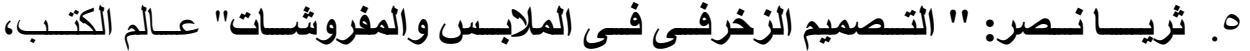

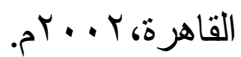

7. جيهان عبد الحميد نوار: " تدريب بعض فئات شباب الخريجين لاتتاج بعض مكملات

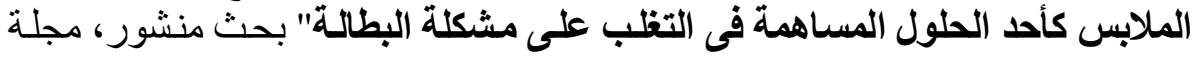

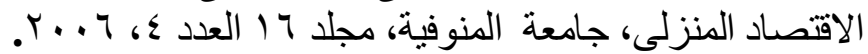

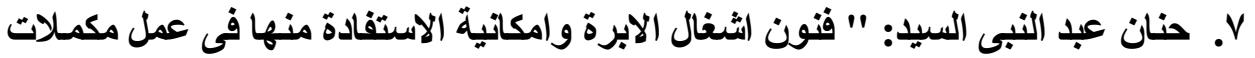

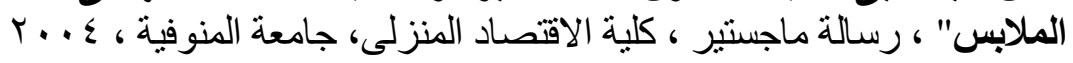

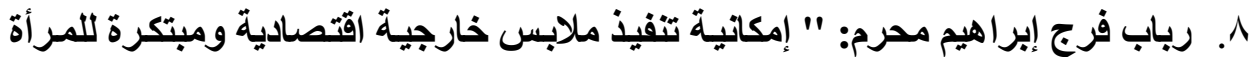

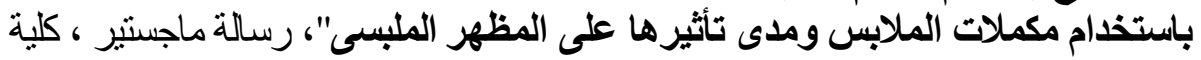

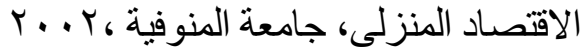

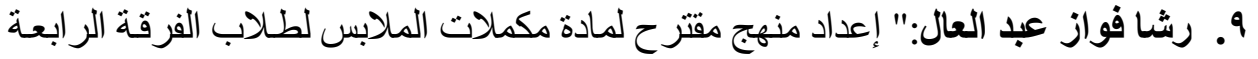

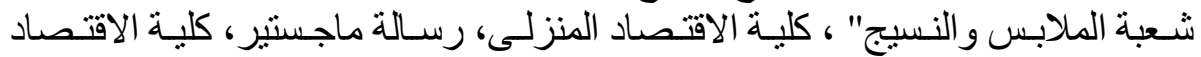

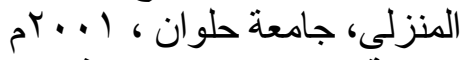

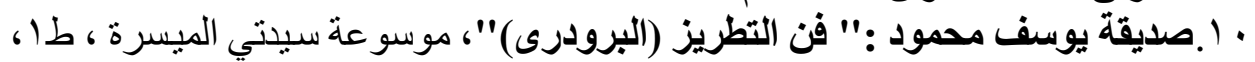

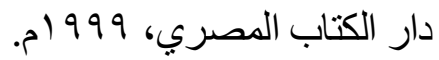

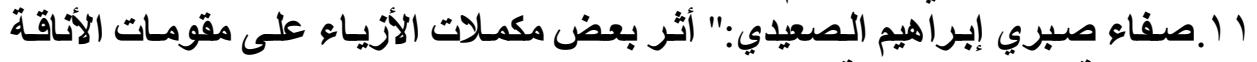

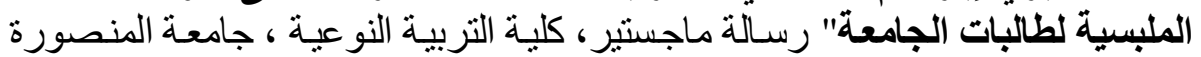
r...r.

r ا .صفاء محمد نعمان: " استخدام اسلوبى الزخرفة النسجية والتطريز فى عمل مكملات

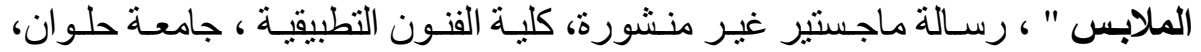
r. ب ا ـ عبد القتاح ريـاض:" التكوين فى الفنون التشكيلية" دار النهضة العربيـة، القـاهرة ، . 999 ـ ا ـ عبــ المـنعم صسبري وآخـرون:" معجـم مـصطلحات الـصناعات النسـية" ألمانيـا

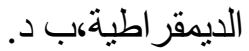

0 ا غادة شاكر عبد الفتاح عفيفى :" المزج بين طباعة المنسوجات والتطريز في تصميم

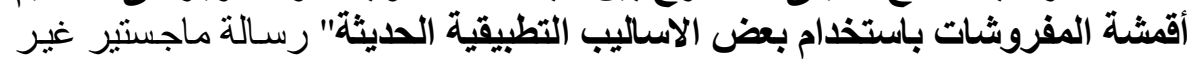

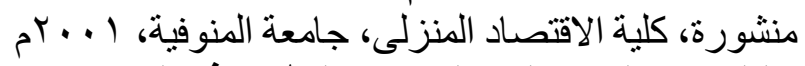

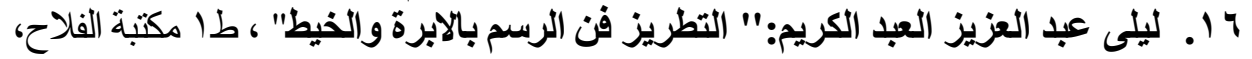

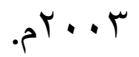

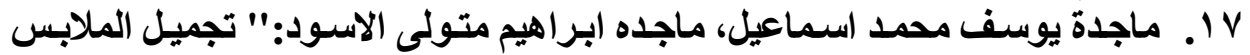

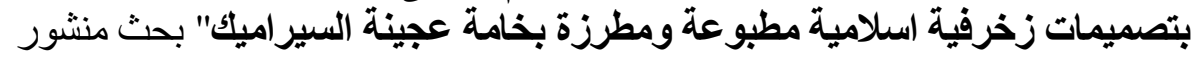

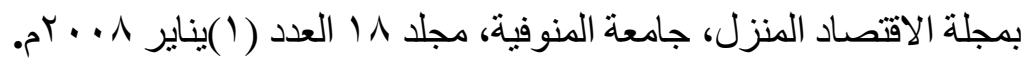

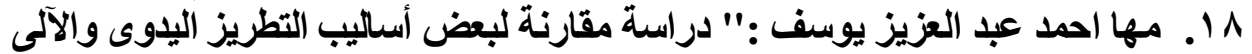

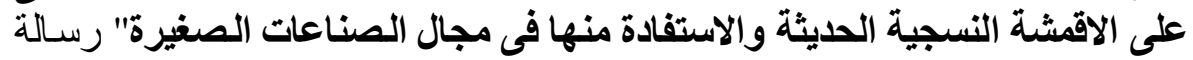

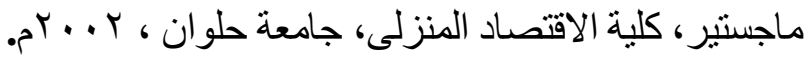




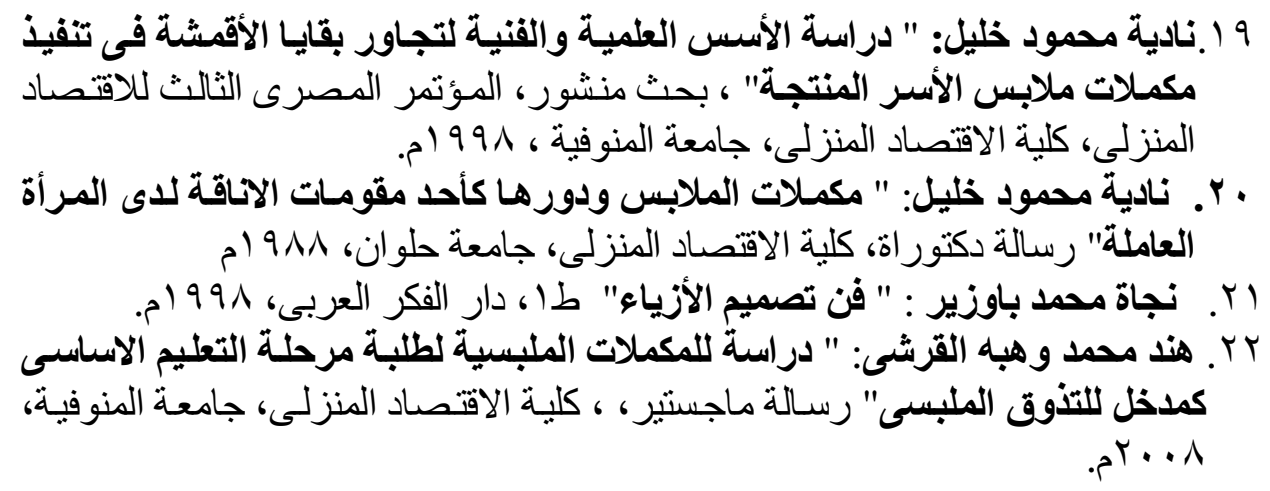

23.Amelia Saint George: " TheNeedle point cross stitch books" London, conran octopus limted, 1992

24.Barbara Snook : " The creative art of embroidery" NewYork. Hamlyn, 1985. 25.Caroline, Ollard: " The complete Book of needle crafts" Eaglenoss publications limited, 1984.

26.Dorothy Wood:' Step-By-step Embroidery stitches" London, Anness publishing limited, 2008.

27.Dorothy Wood:' cross stitch the essential practical collection" London, Anness publishing Ltd,1996.

28.Gerald Knox: " Needle point " Better Homes and Gardens -UsA, 1978.

29.Rosemary Carnelius, Pegdoffek: " Teaching needle craft-Ahand book for beginning instructor" - van no strand Reinhold campany - Newyork, 1979

30. Susan Higginson:" Needle point stitches" Britain, search press Ltd, 2007. 


\title{
USING ETAMIN AS A MEAN FOR TRANSFERRING SOME OF PRINT EFFECTS TO DECORATE AND EMBROIDER THE ACCESSORIES OF THE CLOTHES PRODUCED FROM FABRICS TO SUIT WORKING WOMAN.
}

\author{
Rasha A. M. M. EL- Gohary
}

Home Economic Department the Faculty of Specific Education, Mansoura University, Mansoura, Egypt

\begin{abstract}
The research aims at benefiting from Etamin fabric as a medium in the print process of using stencil on linen as a substitute for raveling to embroider clothes accessories accompanied by employing both of stencil print method and embroidery to beautify and decorate the accessories that allow the working woman to use them, therefore achieving neat appearance as well as the economy in cost.

The research confirmed the possibility of using the produced accessories by the working woman (research subject). It also confirmed the importance of the accessories produced from fabrics for the working woman as the accessories are considered of a great importance in the completion of the general appearance of the woman's clothes and the possibility of achieving artistic decorative and utilitarian values of the accessories through using fabric print and embroidery.
\end{abstract}

Keywords: Etamin, transferring some of print, decorate \& embroider, working woman. 